\title{
The long-term evolution of the Congo deep-sea fan: A basin-wide view of the interaction between a giant submarine fan and a mature passive margin (ZaiAngo project)
}

\author{
Zahie Anka ${ }^{\mathrm{a}, \mathrm{b},{ }^{*},}$, Michel Séranne ${ }^{\mathrm{b}}$, Michel Lopez $^{\mathrm{b}}$, Magdalena Scheck-Wenderoth $^{\mathrm{a}}$ and Bruno \\ Savoye

\footnotetext{
${ }^{a}$ GeoForschungsZentrum Potsdam (GFZ), Section 4.3. Telegrafenberg, 14473 Potsdam, Germany

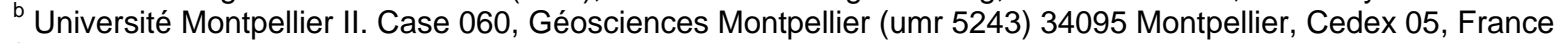

c IFREMER, Géosciences Marines, BP 70 - 29280 Plouzané, France
}

*: Corresponding author : Anka Z., Tel.: +49 331288 1798; fax: +49 331288 1782, email address : zahie@gfz-potsdam.de

\begin{abstract}
:
We have integrated the relatively unknown distal domains of the Lower Congo basin, where the main depocenters of the Congo submarine fan are located, with the better-constrained successions on the shelf and upper slope, through the analysis of thousands of $\mathrm{km}$ of 2D seismic reflection profiles offshore the Congo-Angola passive margin. The basin architecture is depicted by two ca. 800-km-long regional cross sections through the northern (Congo) and southern (Angola) margin. A large unit deposited basinward of the Aptian salt limit is likely to be the abyssal-plain equivalent of the upperCretaceous carbonate shelf that characterized the first post-rift deposits in West-equatorial African margins. A latest-Turonian shelf-deepening event is recorded in the abyssal plain as a long period (Coniacian-Eocene) of condensed sedimentation and basin starvation. The onset of the giant Tertiary Congo deep-sea fan in early Oligocene following this event reactivates the abyssal plain as the main depocenter of the basin. The time-space partitioning of sedimentation within the deep-sea fan results from the interplay among increasing sediment supply, margin uplift, rise of the Angola salt ridge, and canyon incision throughout the Neogene. Oligocene-early Miocene turbidite sedimentation occurs mainly in NW-SE grabens and ponded inter-diapir basins on the southern margin (Angola). Seaward tilting of the margin and downslope salt withdrawal activates the up-building of the Angola escarpment, which leads to a northward (Congo) shift of the transfer zones during late Miocene. Around the Miocene-Pliocene boundary, the incision of the Congo submarine canyon confines the turbidite flows and drives a general basinward progradation of the submarine fan into the abyssal plain The slope deposition is dominated by fine-grained hemipelagic deposits ever since.
\end{abstract}

Results from this work contribute to better understand the signature in the ultra-deep deposits of processes acting on the continental margin as well as the basin-wide sediment redistribution in areas of high river input.

Keywords: West Africa Margin; Angola escarpment; Salt tectonics; Submarine canyon; Lower Congo basin; Submarine fan 


\section{1.- Introduction}

The Congo deep-sea fan is one of the largest submarine fan systems in the world and one of the most important depocenter in the eastern south Atlantic. The fan developed during the post rift evolution of the continental margin of West-equatorial Africa, which was formed following early Cretaceous rifting. It is currently sourced by the Congo River, whose continental drainage area is the second largest in the world $\left(3.710^{6} \mathrm{~km}^{2}\right)$ (Droz et al., 1996) (fig 1). Extending over $1000 \mathrm{~km}$ offshore the Congo-Angola continental margin, from the shelf up to the abyssal plain, this submarine fan covers a surface of about $300,000 \mathrm{~km}^{2}$ (Savoye et al., 2000; Droz et al., 2003) and contains at least $0.7 \mathrm{Mkm}^{3}$ of Tertiary sediments (Anka and Séranne, 2004). The existence of a direct connection between the Congo River mouth and the submarine fan through an impressive submarine canyon is one of the most important characteristics of this system. The Congo canyon cuts across the margin, it is $950 \mathrm{~m}$ deep at the shelf-break and more than $1300 \mathrm{~m}$ at $100 \mathrm{~km}$ offshore the coastline (Babonneau et al., 2002). Thus terrigenous material coming from the continental drainage basin are transported through the canyon and directly transferred onto the abyssal plain, by-passing the shelf and upper slope (Droz et al., 2003; Turakiewicz, 2004).

Due to its economical relevance, the Lower Congo basin has been extensively studied since the sixties (e.g. (Brognon and Verrier, 1966) until recent basin-wide initiative as the ZaiAngo project, a research collaboration between the Ifremer and Total. The continental margin architecture, as well as the stratigraphy of the proximal areas, has been rather well constrained due to the presence of numerous oil wells on the shelf and upper slope (e.g.(Teisserenc and Villemin, 1989; Séranne et al., 1992; Meyers et al., 1996; Rasmussen, 1996; Nzé Abeigne, 1997; Uenzelmann-Neben et al., 1997; Karner and Driscoll, 1999; Anderson et al., 2000; Lavier et al., 2000; Marton et al., 2000; Mougamba et al., 2000; Rosendahl and Groschel-Becker, 2000; Valle et al., 2001; Ardill et al., 2002; Lucazeau et al., 2003; Robin et al., 2005; Petzet, 2007). In addition, some regional works provided some hints 
on the regional significance of the distal provinces and an idea of the deep fan size (Emery et al., 1975; Uchupi, 1989; Uchupi, 1992). More recently, other studies have provided a better understanding of the stratigraphy and evolution of the abyssal plain, where the main fan depocenters are located (Anka, 2004; Anka and Séranne, 2004). Nevertheless, a comprehensive integration of proximal and distal domains, assessing a global basin-wide view of the fan evolution is yet to be carried out.

This contribution complements previous work done in the abyssal plain of the Lower Congo basin and addresses questions regarding the sediment partitioning between the deepsea fan and the continental margin, its timing and controlling factors. We focus on analysing how different processes known to affect the margin, such as submarine erosions, salt tectonics, basin tilting, and continental uplift, are recorded in the distal deposits of the lower slope and abyssal plain, and to what extent they control the submarine fan deposits. We present the results from analysis of 2D seismic reflection data on the slope north of the Congo Canyon that, once correlated to wells in the shelf domain and integrated to the distal seismic, allow to (1) re-interpret and better age-constrain the relatively unknown distal units deposited onto the oceanic crust, (2) analyse the possible interactions between the salt tectonics and the fan depocenter location/migration, and (3) reconstruct the basin-wide architecture proposing a long-term evolution for the Congo deep-sea fan.

\section{2.- Geological setting}

The Congo-Angola passive margin results from Neocomian rifting of Gondwana followed by oceanic accretion (Rabinowitz and Labreque, 1979). Although no magnetic anomaly is found in the Lower Congo basin, the age of the oldest oceanic crust is interpreted to be close to Chron M0 (118.7 Ma), that is Aptian (Nürnberg and Müller, 1991) or even older: Barremian (Marton et al., 2000). Moreover, a literature review reveals that the estimated ages in this area range from 127 to 117 Ma (Teisserenc and Villemin, 1989; Guiraud and Maurin, 1992; 
126 Karner and Driscoll, 1999; Jackson et al., 2000). The precise location of the Continent-Ocean

127 boundary (COB) is rather unknown, but it would correspond to a narrow transition zone

128 between extended continental crust and normal oceanic crust, located few kilometres 129 landward of the Angola escarpment (Fig.1) (Moulin, 2003; Contrucci et al., 2004; Séranne 130 and Anka, 2005).

Following the continental break-up, a transgressive clastic succession, from fluvial sandstones to lagoon shales, accumulates in the basin (Fm. Chela, Fig 2). They are overlain by a thick evaporitic level deposited in restricted marine conditions during late Aptian (Fm. Loeme, Fig 2) (Emery et al., 1975; Teisserenc and Villemin, 1989). This layer, composed mostly of massive halite topped by anhydrite, is the detachment level of the widespread salt 136 tectonics that affects overlaying post-rift sequences (Duval et al., 1992; Lundin, 1992; Vendeville and Jackson, 1992; Gaullier et al., 1993; Spathopoulos, 1996; Cramez and Jackson, 2000; Fort et al., 2004; Jackson and Hudec, 2005; Hudec and Jackson, 2007). aggrading ramp-profiled shelf. As sea-floor spreading goes on, open marine conditions

141 establish and carbonate production is halted. In consequence, from the Cenomanian to the

142 Eocene the sedimentation is characterized by the mudstones and marine siliciclastics of the 143 Iabe/Landana Groups (Fig 2) and depositional rates remain very low throughout this time 144 span (Anderson et al., 2000; Valle et al., 2001).

145 The early Oligocene is characterized by a major submarine erosion that removed as 146 much as $500 \mathrm{~m}$ of sediments of the outer shelf (Nzé Abeigne, 1997; Lavier et al., 2000). This 147 event is linked to the so-called "Oligocene unconformity" identified throughout the West 148 African margin (Teisserenc and Villemin, 1989). Early Oligocene is also a time of a 149 widespread stratigraphic reorganization along the margin, expressed by a generalized turn150 over in the depositional pattern from aggradation to progadation deposits (Séranne et al., 151 1992). An important increase in terrigenous supply is also registered at this time, which is 
evidenced by the development of the massive Congo deep-sea fan in the abyssal plain (Anka and Séranne, 2004). The origin of these widespread changes is still matter of discussion. They may result either from changes in climatic and oceanographic conditions (Séranne, 1999; Lavier et al., 2000) or from epeirogenic motions related to the uplift of the African continent (Bond, 1978; Walgenwitz et al., 1990; Lunde et al., 1992; Walgenwitz et al., 1992; Burke, 1996), and most likely by the interplay among them.

Another erosive event is registered in the West African margin during early Neogene. AFT chronothermometry and fluid inclusion analysis place it around $22 \mathrm{Ma}$, that is early Miocene (Brice et al., 1982; Lunde et al., 1992; Walgenwitz et al., 1992; Valle et al., 2001). It is associated to a general seaward margin tilting (Brice et al., 1982; Lunde et al., 1992; Walgenwitz et al., 1992; Valle et al., 2001). Two-dimensional restoration performed across the northern Angolan margin suggests another minor uplift during late Miocene (Tortonian) (Lavier et al., 2000; 2001). Additionally, sediment supply increases steadily during the Neogene, which in junction to these proposed uplifts, renewed the gravity-driven extension on the shelf and upper slope.

As sedimentary loading enhanced upslope salt tectonics on the shelf and upper-slope, a variety of extensional structures developed: seaward-dipping rotational growth faults, salt diapirs, detached blocks and rafts, and salt rollers, which have been extensively studied over the past years (e.g. (Burrollet, 1975; Duval et al., 1992; Lundin, 1992; Vendeville and Jackson, 1992; Gaullier et al., 1993; Spathopoulos, 1996; Cramez and Jackson, 2000; Broucke et al., 2004; Fort et al., 2004; Jackson and Hudec, 2005; Hudec and Jackson, 2007). This upslope thin-skinned extension is transferred downslope and balanced by the development of compressional structures as imbricate thrusting, large scale diapirs, salt walls, and canopies in the lower slope (Spathopoulos, 1996; Marton et al., 2000; Anka, 2004; Fort et al., 2004; Gottschalk et al., 2004; Jackson et al., 2004; Kilby et al., 2004; Rowan et al., 2004). The Angola escarpment, an impressive north-south bathymetric step at the present-day base 
178 of the Angolan slope (Fig.1), is the seaward limit of a thrust front (the "massive salt")

179 resulting from this compressional salt tectonics.

\section{3.- Data and methodology}

This study is based on a large seismic reflection dataset acquired during the ZaiAngo Project (Savoye et al., 2000). We interpreted more than $19.000 \mathrm{~km}$ of 2D multi-channel seismic reflection lines located between the lower slope and the abyssal plain of the Lower

surveys: (1) 6-channeled high-resolution reflection, (2) 96-channeled high-resolution reflection, and (3) deep penetration reflection-refraction (DST). Additionally, several hundreds of kilometres of high-quality industrial seismic reflection lines located in the northern slope were supplied by Total. These profiles provided the link between the slope deposits and the submarine fan deposits in the abyssal plain, the base of the present-day slope being represented by the salt limit (Fig 3). Altogether the final seismic grid covered a total area of about $200.000 \mathrm{~km}^{2}$ between $2000 \mathrm{~m}$ and $5000 \mathrm{~m}$ of bathymetry.

Penetration to more than $9 \mathrm{~s}$ TWT, permitted to analyse the entire seismostratigraphic record of the abyssal plain down to oceanic crust. The seismic profiles were analysed with the seismic interpretation \& visualization software Sismage Research ${ }^{\mathrm{TM}}$, following a conventional 2D interpretation methodology of delimitation of high amplitude reflectors,

197 generation of surface-depth and isopach maps, long-distance well-seismic correlation, and 198 seismic attribute extraction. The "seismic unit" and "seismic facies" concepts correspond to those proposed initially by Sangree and Widmier (1979). The geological interpretation of the seismic units was based upon the variations of seismic parameters, such as amplitude, 201 frequency, continuity, and external and internal geometries, as well as on the classical 202 concepts of sequence stratigraphy (Vail et al., 1977). However, the interpretation of 203 depositional environments from seismic data requires a link between the character of the 
seismic data and sedimentary facies. The absence of boreholes in the abyssal plain does not allow a direct tie of the seismic facies to lithology data. Hence, we also used the seismic signature of the sedimentary facies in the present-day submarine fan, in order to identify and interpret the distal seismic facies of older deposits (Fig. 4).

The age control relies on: (1) long-distance correlation of the distal seismic reflectors identified in the abyssal plain with more proximal, better age-constrained, reflectors in the slope, (2) north-eastern extended correlation towards the south Gabon basin where seismic markers are already dated from previous works, and (3) seismic-well ties in the platform. This methodology allowed us to establish a long-term chrono-stratigraphic framework that correlates deposits in the upper slope/shelf with the distal units in the abyssal plain.

\section{4.- Seismic stratigraphy and chronology}

A detailed description of the units basinward of the salt limit has been presented in earlier contributions (Anka, 2004; Anka and Séranne, 2004). Fig 5 shows the general distribution of the main seismic units and reflectors identified at the transition between the lower slope and the abyssal plain. As said, the base of the present-day slope corresponds in subsurface to the limit of the Aptian evaporite level, which is interpreted as toe-thrust of the salt layer over the oldest unit deposited over the oceanic crust.

\section{A1: Basal unit overlaying the Aptian salt (Albian-Turonian).}

The first highest-amplitude reflector identified above the salt level, “TC”, represents the boundary between a basal seismic unit A1 composed of high-amplitude, continuous, parallel to sub-parallel internal reflectors and an overlying unit (A2) of low-amplitude,

227 discontinuous internal reflectors. On the lower slope, A1 is highly deformed by diapirs and 228 thrusting associated to downslope compressive salt tectonics. 
The nature of seismic marker TC varies as we trace it from the basin towards the slope. In the abyssal plain, it correlates with a prominent, high-amplitude reflector identified throughout the basin, which represents the upper boundary of the earliest sedimentary unit deposited onto the oceanic crust (Fig. 5). This basal unit reaches a thickness of more than $1 \mathrm{~s}$

TWT at about $100 \mathrm{~km}$ west of the salt limit. Eastward of this limit, on the upper-slope, we observe truncations of the internal reflections, which indicate that reflector TC is indeed the lower slope/abyssal plain correlative surface of this angular unconformity identified in the upper-slope (Fig. 6).

The estimated age of TC is rather variable whether we correlate it to the northern or southern shelf domain. A northeast correlation with seismic profiles in the Gabon basin suggests that TC may represent the seismic reflector 14 described by Nzé Abeigne (1997), and interpreted as the top of Fm. Cap Lopez, dated as earliest Turonian. On the other hand, to the southeast, Valle et al. (2001) identified in the Angolan margin a conspicuous seismic reflector "nt-Cret" at around the same stratigraphic level of TC, which presents similar 243 seismic characteristics. According to these authors, this reflector is aged as late Maastrichtian. 244 Nevertheless, correlations to the Congo shelf indicate that TC may be indeed equivalent to a sequence boundary (MS2) represented by a prominent seismic reflector. This boundary has 246 been placed at the top of the CoXIVa palynological zone, that is, latest Turonian (Massala et 247 al., 1992). We favoured this datation, supported by data from internal reports (courtesy of 248 Total), indicating that sequence boundary "MS2" defines the switch from shelf limestone 249 deposits to marine shale sediments. Thus, we infer that the high amplitude of TC, as well as the variation in seismic character of upper (A2) and lower (A1) units, results from the large impedance contrast between the different lithologies of overlying and underlying deposits.

252 Hence, TC would be the lower-slope equivalent to the described sequence boundary on the 253 shelf. 
These findings modify significantly our previous interpretation where, in the absence

of correlation with nearby wells and based only in comparisons with regional seismic profiles (Musgrove and Austin, 1984) and DSDP Leg 75 Site 530 near the Walvis Ridge, TC was interpreted as the Eocene-Oligocene boundary.

In summary, the basal unit A1 deposited on the oceanic crust, top-bounded by reflector TC, represents the Albian-Turonian sedimentation in the abyssal plain. Thus, it is the ultra-deep lateral equivalent of the carbonate ramp-profiled shelf (Pinda Group and Loango Fm.) that characterized the first stages of post-rift sedimentation on the shelf of the Congo margin.

\section{A2: Basinward-thinning unit (post -Turonian - Eocene).}

Overlying the basal unit A1, and bounded by reflector BO, there is a unit less than 0.4 s TWT thick (A2). It is composed by low amplitude, parallel, discontinuous reflectors (Fig. 6). The unit thins progressively basinward and, at around $200 \mathrm{~km}$ west of the salt limit, it is either below seismic resolution or absent (Fig. 5). As mentioned above, the variation in the seismic signature of this unit may result from the lithology variation between the most-likely carbonates of underlying unit A1 and the probably shaly sediments that make up this unit.

North-east correlation and well datation of top reflector BO point to an age base of the Oligocene - south Gabon prominent reflector 5 of Nzé Abeigne (1997). The small thickness, as well as the eventual basinward pinch-out of the unit, correlates well with the low sedimentation rates reported in the shelf (Anderson et al., 2000; Valle et al., 2001). Based on these results, this relatively thin unit would represent a long time interval of about $65 \mathrm{My}$, from the Coniacian to the Eocene, characterised by very low or condensed sedimentation in the deep basin. 


\section{A3: Basinward-thickening wedge (Oligocene-Miocene).}

In contrast to the basinward thinning of the post-Turonian - Eocene succession, the overlying unit A3 is a basinward diverging wedge whose thickness increases dramatically, from about $0.5 \mathrm{~s}$ TWT in the lower slope to more than $1.5 \mathrm{~s}$ TWT beyond its base (Fig 5). The basal boundary BO, correlates landwards with a major regional unconformity, the "Oligocene unconformity", identified throughout the west African margin (e.g. (Massala et al., 1992; Séranne et al., 1992; McGinnis et al., 1993; Meyers et al., 1996; Rasmussen, 1996; Mauduit et al., 1997; Nzé Abeigne, 1997; Karner and Driscoll, 1999; Mougamba, 1999; Séranne and Nzé Abeigne, 1999; Cramez and Jackson, 2000; Lavier et al., 2000). Although its origin is still controversial, on the Congo margin it represents a large-amplitude submarine erosion in intermediate water depths of $500-1500 \mathrm{~m}$ that removed about $500 \mathrm{~m}$ of sediments (Séranne et al., 1992; McGinnis et al., 1993; Nzé Abeigne, 1997; Lavier et al., 2000; 2001). In southern Gabon, this unconformity is related to a hiatus of at least $15 \mathrm{My}$ on the shelf and upper slope (Teisserenc and Villemin, 1989).

The upper boundary of the unit is depicted by the highest-amplitude reflector identified in the northern slope: reflector R (Figs. 5, 6). This marker is also found on the south Gabon and the Congo-Angola margins. Some authors have interpreted it as the transition between middle Eocene and late Oligocene based upon correlation with ODP leg 175 (Uenzelmann-Neben et al., 1997; Uenzelmann-Neben, 1998). However, none of the sites 1075, 1076, 1077 reached indeed the reflector's depth (Shipboard-Scientific-Party, 1998). North-eastern correlation with the southern Gabon slope, suggests an age probably latest Miocene / base of Pliocene. This result coincides with several academic publications based on internal reports from oil companies (e.g. (Gay, 2002; Turakiewicz, 2004). Consequently, the unit A3 comprises the early Oligocene-Miocene sedimentation span. Its seismic characteristics greatly differ from underlying units, as it is mainly composed of packets of highly discontinuous, wavy, and high amplitude internal reflectors (Fig. 6). This seismic 
configuration is similar to the seismic signature of the turbidite channel facies described in most deep-sea fans and in the Quaternary Congo fan (Lopez, 2001) (Fig. 4). Hence, we interpret the unit as a succession of turbidite channels from the Tertiary Congo submarine fan.

Interesting enough is the fact that, in the upper slope, these deposits are onlapping the base-of-the-Oligocene surface (Fig. 7). This architecture depicts a drastic modification in the stratigraphic pattern from the continuous aggradation of underlying successions A1-A2. These observations support an early-Oligocene onset of the submarine fan as we previously proposed from work carried out basinward of the salt limit.

\section{A4: Upward \& basinward facies change (Pliocene-Recent).}

This unit consists of a package, about $0.8 \mathrm{~s}$ TWT thick, of highly continuous, parallel, low-to-moderate amplitude reflectors that cover most of the present-day northern slope (Fig. 7). By comparison with the seismic facies of the Quaternary fan, it can be interpreted as facies of slope hemipelagics (Fig. 4). Moreover, the unit can be traced landwards where ODP Leg 175, site 1077, recovered hemipelagic deposits composed of diatom and nannofossil-rich clays (Shipboard-Scientific-Party, 1998), which validates the seismic interpretation. This indicates that around reflector $\mathrm{R}$ time, that is the Miocene-Pliocene boundary, the OligoMiocene turbidite deposits of underlying unit A3 are vertically replaced by these hemipelagics. In addition, A4 is affected by densely distributed, multiple, low-displacement vertical faults linked in polygonal networks, which are probably related to upward expulsion of fluids in the slope (Gay et al., 2004; Gay et al., 2006).

At about $200 \mathrm{~km}$ offshore the coast the internal reflection pattern shows a pronounced variation suggesting a lateral modification of the unit's depositional environment. Not only the thickness of the unit increases basinwards to more than $1.5 \mathrm{~s}$ TWT, but also the continuous-parallel reflectors of the hemipelagics facies change to a stacked-onlapping 
channel-like geometry (Fig. 8). Around the same location, the basal boundary -reflector Rdeepens for more than $1 \mathrm{~s}$ TWT and is disrupted by these interpreted channels, so it can not be identified further basinwards. These observations indicate that, since the latest Mioceneearliest Pliocene, there is a basinward shift of the submarine channel facies and thus a general progradation of the entire submarine fan. This process is concomitant to the above-described vertical substitution of channel facies by hemipelagic deosits on the northern slope. We will address the possible mechanisms behind these events later on.

\section{Discussion}

\section{Basin architecture and fan evolution}

We generated two regional sections, more than $600 \mathrm{~km}$ long, across the northern (Congo) and southern (Angola) lower slope and abyssal plain. We have also integrated published sections on the shelf and upper slope domains (Lavier et al., 2001) so the basin architecture is depicted along about $800 \mathrm{~km}$ covering the entire continental margin and oceanic domains (Fig. 9). As mentioned before, the nature of the crust beneath the salt limit is unknown, but it would be either proto-oceanic (Meyers et al., 1996) or transitional (Marton et al., 2000; Moulin, 2003). In contrast to the northern slope, where salt-related gravitational gliding of the sedimentary cover is mostly Oligocene, salt rising along the southern slope has been active until the present, building up the so-called Angola escarpment (Figs. 3 \& 9).

The thickness of the Albo-Turonian unit remains almost constant along the upper and lower slope across the Congo margin, whilst it decreases towards the base of the slope in the Angolan margin. This is consistent with the ramp morphology described by other authors in the Angolan upper slope (Massala et al., 1992; Anderson et al., 2000; Lavier et al., 2001). On the other hand, the significant thickness (about $2 \mathrm{~km}$ ) accumulated at, and beyond the base of the slope is especially surprising and seems to challenge former ideas of very-thin or nearly- 
absent upper-Cretaceous accumulations in the abyssal plain of the basin (Leturmy et al., 2003; Lucazeau et al., 2003; Evans, 2004).

The thinning of the post-Turonian-Eocene section allows inferring a pinch-out at about $250 \mathrm{~km}$ from the salt limit (Fig. 9). Well logs on the Congo shelf register a deepening during Palaeocene-Eocene, contemporaneous with a very low sedimentation rate in the upper slope (Anderson et al., 2000; Valle et al., 2001). Although, this section may be eroded in the Angolan shelf, north-south correlations with strike seismic lines indicate that it is present over the Angolan slope with a thickness up to $500 \mathrm{~m}$. The presence of the massive salt walls associated to the Angola escarpment makes seismic correlation towards the abyssal plain across the Angola margin rather difficult. Nevertheless, in the outer abyssal plain, where the unit is no longer identifiable, the Coniacian-Eocene sedimentation interval would be condensed in reflector TC. Thus, TC is a diachronic seismic marker in the abyssal plain, where it represents a condensed sedimentation span of about $65 \mathrm{My}$. Therefore, the paleobathymetry increase identified in the Congo shelf and slope translates into a long period of basin starvation in the abyssal plain.

As a consequence of the Congo fan onset in early Oligocene, the distal abyssal plain was reactivated as a major depocenter. The Oligo-Miocene wedge is much larger than previously thought, and considerably thicker than the underlying and overlaying deposits (Fig. 9). Although, some authors place the boundary of the Tertiary fan around the presentday salt limit (Kolla et al., 2001), it is shown here that this unit reaches maximum thickness basinward of this limit.

Another result worth discussing is that although the fan deposits are thicker in the southern shelf/upper slope (Angola) than in the northern slope (Congo), both sections show a similar thickness on the abyssal plain. Previous works, restricted to the proximal domains, suggested that the apparent thickness variation resulted from a different capacity of each margin to record climatic vs. geodynamic signals. For instance, on the Angola margin where 
the sediments were transported by the Congo river, whose watershed is influenced by on-land climate variations, the climatic signal would be more dominant. In contrast, on the Congo margin, where sediments were thought to be sourced from the shelf erosion by coastal rivers, geodynamics signals as continental uplift would be better recorded in the deposits (Lavier et al., 2001). However, since the fan deposits are homogenously distributed throughout the abyssal plain, depicting a clear radial fan-shaped depocenter around the present-day Congo River outlet (Fig. 10) we propose that, despite some possible contribution from coastal rivers, the main sediment supplier for both margins is the Congo river, and the variation in thickness between the Congo and Angola slopes is mainly due to their respective paleo-geographic positions with respect to the fan deposits.

The fact that the Tertiary submarine fan overlies the correlative surface of the prominent "Oligocene unconformity" leads us to consider the fan's onset as one of the important stratigraphic changes that took place following this unconformity in several west African margins: e.g. (1) the development of contourites, deep canyon cutting, and submarine erosions in southern Gabon (Séranne and Nzé Abeigne, 1999), (2) the presence of incised valleys and increased sediment supply in northern Gabon (Mougamba, 1999), and (3) the switch from a general aggradation to a progradational stratigraphic pattern along Westequatorial Africa margins (Séranne, 1999; Séranne and Anka, 2005).

\section{Neogene depocenter migration: salt tectonics and Congo canyon incision.}

It has been shown that on the northern slope there is an upward substitution of turbidite facies by slope hemipelagics since the Miocene-Pliocene boundary, which is simultaneous to a basinward shift of the turbidite channels and a general progradation of the fan system (Fig 8). A possible driving mechanism for these fairly abrupt shifts is the onset of a submarine canyon during latest Miocene-earliest Pliocene. This paleo-canyon, probably located near to the present-day one, acted as a confining transit axis for the turbidite flows and 
the continent-derived clastics are delivered seawards of the previous Oligo-Miocene turbidite deposits. As a consequence, the Oligo-Miocene depocenter becomes a sediment-bypass area where slope hemipelagics is the prevailing sedimentation since the time of canyon incision. The existence and timing of this paleo-canyon is also supported by 3D seismic data, which show a conspicuous lower-Pliocene erosional surface below the Present-day canyon (Ferry et al., 2004). This initial canyon incision has been followed by at least four erosion-filling phases until the Present (Gay, 2002). Its driving causes are still matter of debate, some authors propose an allocyclic -climatic or eustatic- origin (i.e. Babonneau et al. 2004, Turakiewicz, 2004, Ferry et al. 2004), while others suggest a local tectonic origin: graben collapse induced by the movement of a deep basement structure (Cramez \& Jackson, 2000). Another possible cause may be related to an acceleration phase estimated by Lavier et al. (2001) on the margin uplift-rate at about $5 \mathrm{Ma}$. Since this uplift rejuvenation is likely to have caused a relative sealevel low, the initial canyon incision could be a by-product of sub-aerial erosion on the proximal areas.

We have individualized the fan deposits into two, pre- and post- reflector R, intervals: Oligocene-Miocene and Pliocene-Present (Fig. 11). The first period is characterized by two main depocentres: (1) one in the south-eastern upper slope (Angola) roughly oriented NW-SE and parallel to the upslope growth faults, and (2) one to the northwest (Congo), centred on the present-day canyon axis (Fig. 11a). The much thinner Pliocene-Recent deposits show only one depocentre, which is located basinwards of the salt limit (Fig. 11b) and is related to the previously-described general progradation of the submarine fan (Fig. 8) .

The integration of published information from several different sources allows deciphering the relative timing of the turbidite deposits within the two depocenters developed during the Oligocene-Miocene (Fig. 12). In Block 4, located near the south-eastern depocenter on the Angolan margin, lower-Miocene turbidite deposits are replaced by slope hemipelagics during middle Miocene (Anderson et al., 2000). In the western neighbouring 
435 Block 17, the turbidites are found until mid-Miocene and slope hemipelagics replace them 436 since late Miocene (Kolla et al., 2001). In addition, to the west of both blocks, in the massive 437 salt domain we find deformed inter-diapir channel-like deposits that are replaced by slope 438 hemipelagics during late Miocene. This indicates that in the south-eastern depocenter 439 (Angola) the successive replacement of turbidite deposits by slope hemipelagics occurs from east to west. That is, the western part of this depocenter receives turbidite flows for a longer 441 time - until mid-late Miocene- than the eastern part, where the substitution by slope 442 hemipelagics started earlier -by middle Miocene-. Then, from late Miocene to the Present, the dominant deposits throughout this south-eastern depocenter are slope hemipelagics. In 444 contrast, the north-western depocenter (Congo) contains turbidite deposits spanning 445 throughout the Oligocene and Miocene. In fact, a level of upper Miocene channels has been 446 identified (Ferry et al., 2004), which proves that turbidite flows continued to fill this depocenter even after turbidite deposition has already ceased on the south-eastern depocenter 448 (Angola).

All these observations suggest that: (1) Although the north-western depocenter received episodic turbidite flows, the lower-middle Miocene turbidite sedimentation takes place mainly in the south-eastern depocenter (Fig. 11a). (2) Within this depocenter there is a westward migration of turbidite deposits during middle-late Miocene (Fig 12 -1). This event was probably linked to an enhanced downslope salt flow across the Angola margin driven by

454 the combined action of continuous sediment input and the mid-Miocene westward tilting of 455 the margin (Brice et al., 1982; Walgenwitz et al., 1990; Lavier et al., 2000). (3) The relief of the Angola escarpment, which is still building up in the Present (Figs. 3, 9), must have 457 developed during late Miocene at the time of the substitution by hemipelagic facies (Fig 122). (4) As accommodation space decreases across the Angola margin due to the accelerated 459 rise of the salt walls turbidite flows are deflected to the northwest (fig 12-3), where 460 gravitational gliding of the sedimentary cover ceased during the Oligocene (Fig. 9) and 
accommodation space is still available, filling this depocenter until the end of Miocene (Fig. 11a). (5) Then it follows the general basinward migration of the fan's turbidite channels that filled the post-Miocene depocenter while hemipelagic deposition dominates the slope (Figs. 8, 11b). Since the Pliocene to the Present, no turbidite deposition is recorded in the northern slope, but in the abyssal plain.

Based on the findings and the above discussion, we propose that the general timespace partitioning of sedimentation within the deep-sea fan, results from the interplay among margin uplift/tilting, growth of diapirs in the salt ridge, and canyon incision that can be explained as follows:

i) During Oligocene-early Miocene, unconfined turbidite flows were mainly controlled, and directed by the margin-parallel listric faults, associated to extensional salt tectonics, and by inter-diapirs "valleys". Hence, the deposition occurs mainly in NW-SE grabens and in ponded inter-diapir basins in the slope, feeding primarily the south-eastern depocenter (Fig 13a).

ii) Continuous increase in sediment supply and the seaward tilting of the margin during middle Miocene (Brice et al., 1982; Walgenwitz et al., 1990; Lavier et al., 2000) enhances differential loading on the southern margin. Up-dip extensional salt and raft tectonics trigger the gravitational gliding of the sedimentary wedge, which creates additional accommodation space and terrigenous deposits migrate westwards.

iii) The seaward withdrawal of salt that accommodates the upslope extension increases downslope-compressional salt tectonics and activates the up-building of massive salt walls which is still active today- and triggers the development of the Angola escarpment during late Miocene (Fig 13b). Since the sediments are no longer able to cross this massive salt domain the channels connected to the river outlet deflect the turbidite flows to the northwest, driving the northward shift of the transfer zones. 
iv) At the Miocene/ Pliocene boundary, the interaction between the erosion linked to an acceleration on the margin uplift-rate and the instability created by the structural growth of rising diapirs on the salt ridge favours the onset of a paleo Congo canyon, which confined the turbidite flows. Continent-derived sediments bypass the shelf and slope and are delivered directly into the abyssal plain. As a consequence, the whole system progrades basinwards and the slope deposition is dominated by fine-grained hemipelagic deposits ever since (Fig 13c).

\section{6.- Conclusions}

The analysis of 2D seismic reflection data from the abyssal plain and the northern slope of the Lower Congo basin allowed us to integrate these relatively unknown distal domains, where the main depocenters of the Congo submarine fan are located, with the betterconstrained successions in the shelf and upper slope. The results yield a contribution to better understanding the signature in the ultra-deep accumulations of geological processes acting on the continental margin and the resulting partitioning of sediment transport in areas of high river input.

We show that reported low sediment rates during Coniacian-Eocene, associated to a deepening registered in the shelf, are recorded in the abyssal plain as a single very-high seismic amplitude reflector representing a long-period of post-Turonian to Eocene condensed sedimentation and distal basin starvation. Prior to this event, a large Albian-Turonian unit exists, which is likely to be the abyssal-plain equivalent of the upper-Cretaceous carbonate shelf described in the literature.

The onset of the giant Tertiary Congo-deep-sea fan, in early Oligocene, follows the basin starvation event and reactivates the abyssal plain as the main depocenter in the basin. Two regional cross sections running through the Congo and Angola slope and into the deep basin provide the basin-wide architecture and show that the Tertiary fan deposits, although 

Wiedereinstiegsstellen Program of the Helmholtz Association. slope and abyssal plain. the rate of the margin uplift. of the basin.

\section{Acknowledgments}

more important in the Angola margin, are indeed homogeneously distributed in the lower

Our model proposes that the interplay between sediment supply, margin Neogene uplift, and salt tectonics is reflected in the migration of the fan depocenters during the Neogene. Continuous and increasing sediment influx associated to the development of the Tertiary fan, in addition to the westward-tilting of the margin, drives the growth of the massive salt domain and the development of the Angola escarpment, which in turn leads the northwestern migration of the sediment transfer zones during late Miocene. There is a general basinward progradation of the fan depocenter during Pliocene until the Present driven by the incision of the Congo submarine canyon in latest Miocene- early Pliocene. This last might have resulted from erosion associated to the relative sea-level fall triggered by acceleration on

Future work will address the nature of the distal upper-Cretaceous unit, its potential as hydrocarbon source rock and possible relation with gas-leakage features reported in the slope

We thank the crew of the N/O Atalante. Seismic data was acquired and processed thanks to the skills of GENAVIR and IFREMER staff. We are indebted to the IFREMER and to Alain Morash from TOTAL for providing ZaiAngo Project's seismic data, support, and allowing publication of this work. The manuscript benefited from valuable comments of Francois Roure and an anonymous reviewer. Z. Anka's current position at the GFZ is funded by the 


\section{References}

Anderson, J.E., Cartwright, J., Drysdall, S.J. and Vivian, N., 2000. Controls on turbidite sand deposition during gravity-driven extension of a passive margin: examples from Miocene sediments in Block 4, Angola. Marine and Petroleum Geology(17): 11651203.

Anka, Z., 2004. Evolution de l'éventail sous-marin du Zaire (Congo) depuis le Crétacé. Interactions avec la marge continentale du Golfe de Guinée. Ph.D. Thesis, Univ. Montpellier II, 213 pp.

Anka, Z. and Séranne, M., 2004. Reconnaissance study of the ancient Zaire (Congo) deep-sea fan (ZaiAngo Project). Marine Geology(209): 223-244.

Ardill, J., Huang-Ting, C. and McLaughlin, O., 2002. The stratigraphy of the Oligocene to Miocene Malembo Formation of the Lower Congo Basin, offshore Angola. In: A.A.P.G. (Editor), Annual Meeting expanded abstracts., pp. 9.

Babonneau, N., Savoye, B., Cremer, M. and Klein, B., 2002. Morphology and architecture of the present canyon and channel system of the Zaire deep-sea fan. Mar. and Pet. Geol., 19(4): 445-467.

Bond, G., 1978. Evidence for Late Tertiary uplift of Africa relative to North America, South America, Australia and Europe. Journal of Geology(86): 47-65.

Brice, A.H., Cochran, M.D., Pardo, G. and Edwards, A.D., 1982. Tectonics and sedimentation of the South Atlantic rift sequence: Cabinda, Angola. In: J.S. Watkins and C.L. Drake (Editors), Studies in Continental Margin Geology. A.A.P.G. Memoir, Tulsa, pp. 5-18.

Brognon, G.P. and Verrier, G.R., 1966. Oil and geology in Cuanza basin of Angola. American Association of Petroleum Geologists Bulletin, 50(1): 108-158.

Broucke, O., Temple, F., Rouby, D., Robin, C., Calassou, S., Nalpas, T. and Guillocheau, F., 2004. The role of deformation processes on the geometry of mud-dominated turbiditic systems, Oligocene and Lower-Middle Miocene of the Lower Congo basin (West African Margin). Marine and Petroleum Geology, 21(3): 327-348.

Burke, K., 1996. The African Plate. South African Journal of Geology(99): 341-409.

Burrollet, P.F., 1975. Tectonique en radeaux en Angola. Bull. Soc. Géol. Fr., XVII: 503-504.

Contrucci, I., Mathias, L., Moulin, M., Geli, L., Klingekhofer, F., Nouze, H., Aslanian, D., Olivet, J.-L., Rehault, J.-P. and Sibuet, J.-C., 2004. Deep structure of the West African continental margin (Congo, Zaire, Angola) between $5^{\circ} \mathrm{S}$ and $8^{\circ} \mathrm{S}$, from reflection/refraction seismics and gravity data. Geophys. Jour. Int., 158(2): 529-553.

Cramez, C. and Jackson, M.P.A., 2000. Superposed deformation straddling the continentaloceanic transition in deep-water Angola. Marine and Petroleum Geology, 17: 10951109.

Droz, L., Marsset, T., Ondréas, H., Lopez, M., Savoye, B. and Spy-Anderson, F.L., 2003. Architecture of an active mud-rich turbidite system: the Zaire Fan (Congo-Angola margin southeast Atlantic). Results from Zaiango 1 and 2 cruises. AAPG. Bull., 87(7): 1145-1168.

Droz, L., Rigaut, F., Cochonat, P. and Tofani, R., 1996. Morphology and recent evolution of the Zaire turbidite system (Gulf of Guinea). GSA Bulletin, 108(3): 253-269.

Duval, B., Cramez, C. and Jackson, M.P.A., 1992. Raft tectonics in the Kwanza Basin, Angola. Mar. \& Petrol. Geol., 9: 389-404.

Emery, K.O., Uchupi, E., Bowin, C.O., Phillips, J. and Simpson, S.W., 1975a. Continental margin off western Africa: Cape St Francis (South Africa) to Walvis Ridge (South West Africa). AAPG Bull., 59(1): 3-59.

Emery, K.O., Uchupi, E., Phillips, J., Bowin, C. and Mascle, J., 1975b. Continental Margin off Western Africa: Angola to Sierra Leona. A.A.P.G. Bulletin, 59: 2209-2265. 
Evans, D., 2004. Subsurface deposition on the abyssal plain of the Congo fan, AAPG Annual Meeting, Dallas, Texas, USA.

Ferry, J.N., Babonneau, N., Mulder, T., Parize, O. and Raillard, S., 2004. Morphogenesis of Congo submarine canyon and valley: implications about the theories of the canyons formation. Geodynamica Acta, 17: 241-251.

Fort, X., Brun, J.P. and Chauvel, F., 2004. Contraction induced by block rotation above salt (Angolan margin). Marine and Petroleum Geology, 21(10): 1281-1294.

Gaullier, V., Brun, J.P., Guérin, G. and Lecanu, H., 1993. Raft tectonics: the effects of residual topography below a salt décollement. Tectonophysics, 228(3-4): 363-381.

Gay, A., 2002. Les marqueurs géologiques de la migration et de l'expulsion des fluids sédimentaires sur le plancher des marges passives matures. Exemples dans le bassin du Congo. Ph.D. Thesis, Université des Sciences et Technologies de Lille, Lille, France, $426 \mathrm{pp}$.

Gay, A., Lopez, M., Cochonat, P., Séranne, M., Levache, D. and Sermondadaz, G., 2006. Isolated seafloor pockmarks linked to BSRs, fluid chimneys, polygonal faults and stacked Oligocene-Miocene turbiditic palaeochannels in the Lower Congo Basin. Marine Geology, 226(1-2): 25-40.

Gay, A., Lopez, M., Cochonat, P. and Sermondadaz, G., 2004. Polygonal faults-furrows system related to early stages of compaction - upper Miocene to recent sediments of the Lower Congo Basin. Basin Research, 16(1): 101-116.

Gottschalk, R.R., Anderson, A.V., Walker, J.D. and Da Silva, J.C., 2004. Modes of contractional salt tectonics in Angola Block 33, Lower Congo Basin, west Africa., Sediment Interactions and Hydrocarbon Prospectivity, Concepts, Applications and Case Studies for the 21st Century. SEPM, Houston, TX., pp. 705-734.

Guiraud, R. and Maurin, J., 1992. Early Cretaceous rift of western and central Africa: An overview. Tectonophysics, 213: 153-168.

Haq, B.U., Handerbol, J. and Vail, P.R., 1987. Chronology of fluctuating sea level since the Triassic (250 million years ago to Present). Science(235): 1156-1167.

Hudec, M.R. and Jackson, M.P.A., 2007. Terra infirma: Understanding salt tectonics. EarthScience Reviews, 82(1-2): 1-28.

Jackson, M.P.A., Cramez, C. and Fonck, J.M., 2000. Role of subaerial volcanic rocks and mantle plumes in creation of South Antlantic margins: implications for salt tectonics and source rocks. Marine and Petroleum geology, 17: 477-498.

Jackson, M.P.A. and Hudec, M.R., 2005. Stratigraphic record of translation down ramps in a passive-margin salt detachment. Journal of Structural Geology, 27(5): 889-911.

Jackson, M.P.A., Hudec, M.R. and Jennette, D.C., 2004. Insight from a gravity driven linked system in deep-water Lower Congo Basin, Gabon., Sediment Interactions and Hydrocarbon Prospectivity, Concepts, Applications and Case Studies for the 21st Century. SEPM, Houston, TX., pp. 735-752.

Jansen, J.H.F., 1985. Hiatuses in Mesozoic and Cenozoic sediments of the Zaire (Congo) continental shelf, slope, and deep-sea fan. In: K.J. Hsue and H.J. Weissert (Editors), South Atlantic paleoceanography. Cambridge University press, pp. 197-204.

Karner, G.D. and Driscoll, N.W., 1999. Tectonic and stratigraphic development of the West African and eastern Brazilian Margins: insights from quantitative basin modelling; In: N.R. Cameron, R.H. Bate and V.S. Clure (Editors), The Oil and Gas Habitats of the South Atlantic. Geological Society, London, pp. 11-40.

Kilby, R., Jackson, M.P.A. and Hudec, M.R., 2004. Preliminary analysis of thrust kinematics in the lower Congo Basin, dee-water southern Gabon., GSA annual meeting, pp. 505.

Kolla, V., Bourges, P., Urruty, J.M. and Safa, P., 2001. Evolution of deep-water Tertiary sinuous channels offshore angola (west Africa) and implications for reservoir architecture. A.A.P.G. Bull., 85(8): 1373-1405. 
651

652

653

654

655

656

657

658

659

660

661

662

663

664

665

666

667

668

669

670

671

672

673

674

675

676

677

678

679

680

681

682

683

684

Lavier, L., Steckler, M. and Brigaud, F., 2000. An Improved Method for Reconstructing the Stratigraphy and Bathymetry of Continental Margins: application to the Cenozoic Tectonic and Sedimentary History of the Congo Margin. AAPG Bull., 84(7): 923-939.

Lavier, L., Steckler, M. and Brigaud, F., 2001. Climatic and Tectonic Control on the Cenozoic Evolution of the West African Margin. Marine Geology(178): 63-80.

Leturmy, P., Lucazeau, F. and Brigaud, F., 2003. Dynamic interactions between the gulf of Guinea passive margin and the Congo river drainage basin. Part I: morphology and mass balance. J. Geophys. Res., 108(B8): 13.

Lopez, M., 2001. Architecture and depositional pattern of the Quaternary deep-sea fan of the Amazon. Mar. and Pet. Geol., 18: 479-486.

Lucazeau, F., Brigaud, F. and Leturmy, P., 2003. Dynamic interactions between the gulf of Guinea passive margin and the Congo river drainage basin: 2. Isostasy and uplift. J. Geophys.Res., 108(B8): 19.

Lunde, G., Aubert, K., Lauritzen, O. and Lorange, E., 1992. Tertiary uplift of the Kwanza Basin in Angola. In: Curneller (Editor), Geologie Africaine-Compte Rendu des colloques de Geologie de Libreville. Centre Recherche Exploration Production, Elf Aquitaine, pp. 6-8.

Lundin, E.R., 1992. Thin-skinned extensional tectonics on a salt detachment, northern Kwanza Basin, Angola. Mar. \& Petrol. Geol., 9: 405-411.

Marton, L.G., Tari, G.C. and Lehmann, C.T., 2000. Evolution of the Angolan passive margin, West Africa, with emphasis on post-salt structural styles. In: W. Mohriak and M. Talwani (Editors), Atlantic rifts ans continental margins. Geophysical monograph. American Geophysical Union, pp. 129-149.

Massala, A., De Klasz, I., De Klasz, S. and Laurin, B., 1992. translated: Benthic foraminifera of stratigraphic interest from the Congo Basin. In: R. Curnelle (Editor), African geology; First meeting on the Stratigraphy and paleogeography of West Africa sedimentary basins; Second African meeting on Micropaleontology. Elf-Aquitaine Research Centre, pp. 411.

Mauduit, T., Guerin, G., Brun, J.P. and Lecanu, H., 1997. Raft tectonics: effects of basal slope angle and sedimentation rate on progressive extension. J. Structural. Geol., 19(9): 1219-1230.

McGinnis, J.P., Driscoll, N.W., Karner, G.D., Brumbaugh, W.D. and Cameron, N., 1993a. Flexural response of passive margins to deep-sea erosion and slope retreat: Implications for relative sea-level change. Geology, 21: 893-896.

Meyers, J.B., Rosendahl, B.R. and Austin, J.A.j., 1996. Deep-penetrating MCS images of the South Gabon Basin: implications for rift tectonics and post-breakup salt remobilization. Basin Research, 8: 65-84.

Mougamba, R., 1999. Chronologie et architecture des systemes turbiditiques Cenozoique du prisme sédimentaire de l'Ogooué. (Marge Nord-Gabon). Ph.D. Thesis, Université des Sciences et Technologies de Lille, Lille, 219 pp.

Moulin, M., 2003. Etude géologique et géophysique des marges continentales passives : exemple du Zaïre et de l'Angola. Ph.D. Thesis, Universite de Bretagne Occidental, Brest.

Musgrove, L.E. and Austin, J.A.j., 1984. Multichannel seismic reflection survey of the southeastern Angola Basin. In: W.W. Hay, J.C. Sibuet et. al. (Editors), Initial Reports of the Deep Sea Drilling Project. U.S. Government Printing Office, Washington, DC., pp. 1191-1210.

Nürnberg, D. and Müller, R.D., 1991. The tectonic evolution of the South Alantic from Late Jurassic to Present. Tectonophysics, 191: 27-53. 
685

686

687

688

689

690

691

692

693

694

695

696

697

698

699

700

701

702

703

704

705

706

707

708

709

710

711

712

713

714

715

716

717

718

719

720

721

722

723

724

725

726

727

728

729

730

731

732

733

734

Nzé Abeigne, C.R., 1997. Evolution post-rift de la marge continentale Sud-Gabon: contrôles tectonique et climatique sur la sédimentation. Ph.D. Thesis, Université Montpellier II, 2 vol. 195 pp.

Petzet, A., 2007. Exploration spreads into numerous remote and non-producing basins. Oil and gas journal, 105(12): 33-39.

Rabinowitz, P.D. and Labreque, J., 1979. The Mesozoic South Atlantic Ocean and evolution of its continental margins. J. Geophys. Res., 84(B11): 5973-6003.

Rasmussen, E.S., 1996. Structural evolution and sequence formation offshore South Gabon during the Tertiary. Tectonophysics(266): 509-523.

Robin, C., Rouby, D., Granjeon, D., Guillocheau, F., Allemand, P. and Raillard, S., 2005. Expression and modelling of stratigraphic sequence distortion. Sedimentary Geology, 178(3-4): 159-186.

Rosendahl, B. and Groschel-Becker, H., 2000. Architecture of the continental margin in the Gulf of Guinea as revealed by reprocessed deep-imaging seismic data.

Rowan, M.G., Peel, F. and Vendeville, B., 2004. Gravity-driven fold belts on passive margins. In: M.K.R. (Editor), Thrust tectonics and hydrocarbon systems. AAPG, pp. 157-182.

Sangree, J.B. and Widmier, J.M., 1979. Interpretation of depositional facies from seismic data. Geophysics, 44(2): 131-160.

Savoye, B., Cochonat, P., Apprioual, R., Bain, O., Baltzer, A., Bellec, V., Beuzart, P., Bourillet, J.F., Cagna, R., Cremer, M., Crusson, A., Dennielou, B., Diebler, D., Droz, L., Ennes, J.C., Floch, G., Foucher, J.P., Guiomar, M., Harmegnies, F., Kerbrat, R., Klein, B., Khun, H., Landure, J.Y., Lasnier, C., Le Drezen, E., Le Formal, J.P., Lopez, M., Loubrieu, B., Marsset, T., Migeon, S., Normand, A., Nouzé, H., Ondreas, H., Pelleau, P., Saget, P., Séranne, M., Sibuet, J.C., Tofani, R. and Voisset, M., 2000. Structure et évolution récent de l'éventail turbiditique du Zaire: premiers résultats scientifiques des missions d'exploration Zaiango 1\&2 (marge Congo-Angola). Comptes rendus de l'Académie des Sciences de Paris.(331): 211-220.

Séranne, M., 1999. Early Oligocene stratigraphic turnover on west Africa continental margin: a signature of the Tertiary greenhouse to icehouse transition? Terra Nova, 11(4): 135140.

Séranne, M. and Anka, Z., 2005. South Atlantic continental margins of Africa: A comparison of the tectonic vs climate interplay on the evolution of equatorial west Africa and SW Africa margins. Journal of African Earth Sciences. Phanerozoic Evolution of Africa, 43(1-3): 283-300.

Séranne, M. and Nzé Abeigne, C., 1999. Oligocene to Holocene sediment drifts and bottom currents on the slope of Gabon continental margin (west Africa). Consequences for sedimentation and southeast Atlantic upwelling. Sedimentary Geology, 128: 179-199.

Séranne, M., Seguret, M. and Fauchier, M., 1992. Seismic super-units and post-rift evolution of the continental passive margin of southern Gabon. Bull. Soc. Géol. France, 163(2): 135-146.

Shipboard-Scientific-Party, 1998. Site 1075. In: G. Wefer, W.H. Berger and C. Richter (Editors), Proceedings of the Ocean Drilling Program, Initial Reports, Vol. 175. Ocean Drilling Program, College Station, TX, pp. 49-87.

Spathopoulos, F., 1996. An insight on salt tectonics in the Angola Basin, South Atlantic. In: G.I. Alsop, D.J. Blundell and I. Davison (Editors), Salt Tectonics. Geological Society of London, London, pp. 153-174.

Teisserenc, P. and Villemin, J., 1989. Sedimentary basin of Gabon - Geology and oil systems. In: J.D. Edwards and P. A.Santogrossi (Editors), Divergent/Passive Margin Basins. AAPG, Tulsa, OK., pp. 177-199. 
Turakiewicz, G., 2004. Mécanismes forcants dans les éventails turbiditiques de marges matures - Exemple de l'éventail Quaternaire du Congo-. Ph.D. Thesis, Univ. Montpellier II, 367 pp.

Uchupi, E., 1989. The tectonic style of the Atlantic Mesozoic rift system. Journal of African Earth Sciences, 8: 143-164.

Uchupi, E., 1992. Angola Basin: Geohistory and construction of the continental rise. In: C.W. Poag and P.C.d. Graciansky (Editors), Geologic evolution of Atlantic continental rises. Van Nostrand Reinhold, New York, pp. 77-99.

Uenzelmann-Neben, G., 1998. Neogene sedimentation history of the Congo Fan. Mar. Petrol. Geol., 15: 635-650.

Uenzelmann-Neben, G., Spiess, V. and Bleil, U., 1997. A seismic reconnaissance survey of the northern Congo Fan. Mar. Geol., 140: 283-306.

Vail, P.R., Mitchum, R.M. and Thompson, S., 1977. Global cycles of relative changes in sea level. In: C.E. Payton (Editor), Seismic Stratigraphy - applications to hydrocarbon exploration. A.A.P.G., Tulsa,Oklahoma, pp. 83-98.

Valle, P.J., Gjelberg, J.G. and Helland-Hansen, W., 2001. Tectonostratigraphic development in the eastern Lower Congo Basin, offshore Angola, West Africa. Mar. Petrol. Geol.(18): 909-927.

Vendeville, B.C. and Jackson, M.P.A., 1992. The rise of diapirs during thin-skinned extension. Mar. \& Petrol. Geol., 9: 331-353.

Walgenwitz, F., Pagel, M., Meyer, A., Maluski, H. and Monié, P., 1990. Thermochronological approach to reservoir diagenesis of the offshore Angola basin : a fluid inclusion, 40Ar-39Ar and K-Ar investigation. AAPG Bull., 74(5): 547-563.

Walgenwitz, F., Richert, J.P. and Charpentier, P., 1992. Southwest border of African plate; thermal history and geodynamical implications. In: C.W. Poag and P.C. de Graciansky (Editors), Geologic evolution of Atlantic continental rises. Van Nostrand Reinhold, New York, pp. 20-45. 


\section{Figure captions}

\section{Fig.1.}

Location of the Congo deep-sea fan complex in the context of the South Atlantic and the West African margin. The fan is currently sourced by the Congo River whose drainage basin (white line) is about $3.7 \times 10^{6} \mathrm{~km}^{2}$. There is a direct connection between the river mouth and the fan through the Congo submarine canyon, so terrigenous sediments bypass the shelf and slope, and are directly delivered to the abyssal plain, basinward of the Angola escarpment. (Seafloor bathymetry and land topography DEM from Gtopo30).

\section{Fig 2.}

Generalized litho-stratigraphy and main post-rift tectonic events registered on the shelf and upper-slope of Lower Congo basin (compiled and modified from Jansen 1985, Mougamba 1999, Anka and Séranne, 2004, and internal reports from Total).

\section{Fig 3.}

EM12 bathymetry (within the dash-lined rectangle) and 2D seismic reflection dataset from the ZaiAngo project analysed in this work. The grid consists of about $19000 \mathrm{~km}$ seismic profiles and covers an approximate area of 200,000 $\mathrm{km}^{2}$ between 2000 and $5000 \mathrm{~m}$ of bathymetry. The base of the present-day slope is defined by the limit of the Aptian salt basin. White dots in the northern slope are sites from ODP leg 175. Black rectangles are seismic profiles shown in figs. 5-9. The Angola escarpment is an impressive margin-paralleled salt ridge located southwards of the Congo canyon.

\section{Fig 4.}

Block diagram showing the schematic spatial distribution of the facies in the Quaternary fan and their seismic signatures (Droz et al., 2003; Turakiewicz, 2004). These last were used as identification criteria for the seismic facies in the older fan deposits.

\section{Fig 5.}

Uninterpreted (upper panel) and interpreted (lower panel) seismic profile showing the distribution of the seismic units identified around the transition between the slope to the abyssal plain of the Lower Congo basin (see location in figure 3). The base of the present-day slope is defined by a toe-thrust of the Aptian salt level over the most basal oceanic unit A1. The age control of seismic markers was achieved by correlation to wells in the upper-slope and shelf. TC: top Turonian, BO: base of Oligocene, R: boundary Miocene-Pliocene. (The details of each unit are given in the text).

\section{Fig 6.}

Detail of the truncation of high-amplitude, semi-continuous internal reflectors of seismic unit A1 against the unconformity TC in the slope. Note the contrast with the seismic characteristics of overlying unit A2, mainly composed of low-amplitude and discontinuous reflectors, which thins significantly to the West, in the abyssal plain (see location in figure 3).

\section{Fig 7.}

Uninterpreted and interpreted seismic profile across the upper slope showing stacking, discontinuous and high-amplitude reflectors of unit A3 onlapping the base of the Oligocene (see location in figure 3). This pattern differs from the aggradation of underlying units A1-A2, 
which suggests a drastic change in the nature of sedimentary deposits during early Oligocene. Upper-most unit A4 consists mostly of slope hemipelagic deposits and is densely affected by vertical faulting that has been related to upward fluid expulsion (Gay, 2004).

\section{Fig 8.}

Upward substitution of the Oligo-Miocene turbidite deposits of unit A3 by slope hemipelagics of unit A4 on the northern slope during reflector "R" time (Miocene-Pliocene boundary). In turn, the hemipelagic deposits shift to onlapping stacking channels basinwards. This seaward facies change takes place as unit A4 deepens and thickens considerably to the west (see location in figure 3).

\section{Fig 9.}

Regional transects across the Lower Congo basin, covering more than $800 \mathrm{~km}$ from the shelf domain into the abyssal plain. The geometry of the fan deposits is clearly depicted north (Congo) and South (Angola) of present-day Congo canyon. Salt-realted gravity gliding of the sedimentary cover is mostly Oligocene on nothern slope, while it is still active on the south. Note the relative thickness between the Oligo-Miocene deep-sea fan and the Plio-Quaternary. Shelf sections are modified from Lavier et al. (2001). (Read text for details).

\section{Fig 10.}

Isopach map of the Congo deep-sea fan deposits from Oligocene to Present. The main depocenter is homogenously distributed throughout the abyssal plain, and is centred on the present-day axis between the Congo canyon and the active channel. This clearly indicates the Congo River has been the main fan's feeder.

\section{fig 11.}

Isopach maps of the a) Oligocene-Miocene (unit A3) and b) Pliocene-Present (unit A4) deposits. The Oligo-Miocene succession presents two main depocenters located to the southeast, landward of the massive salt, and to the northwest, basinward from the salt limit. In contrast, the Pliocene-Present deposits are rather thin and present only one depocenter to the northwest. (The thin dashed line depicts the limit of the facies change in unit A4 shown in fig.8).

\section{Fig 12.}

Synthetic map depicting the relative timing and location of turbidite deposits within the 2 Oligocene - Miocene depocenters, based on published information. (1) During mid-Miocene there is a seaward migration of turbidite deposits on the southern slope (Angola) (2) No turbidite deposition is recorded on this slope since late Miocene, only hemipelagics (3) During late Miocene turbidite flows are redirected to the northwest (Congo) where four levels of turbidites are identified during the Oligocene- Miocene.

\section{Fig 13.}

Block diagram showing the proposed Congo submarine fan evolution since the Oligocene, and the interaction among the development of the Angola escarpment, the fan depocenter migration, and the submarine canyon incision. (See text for details). 


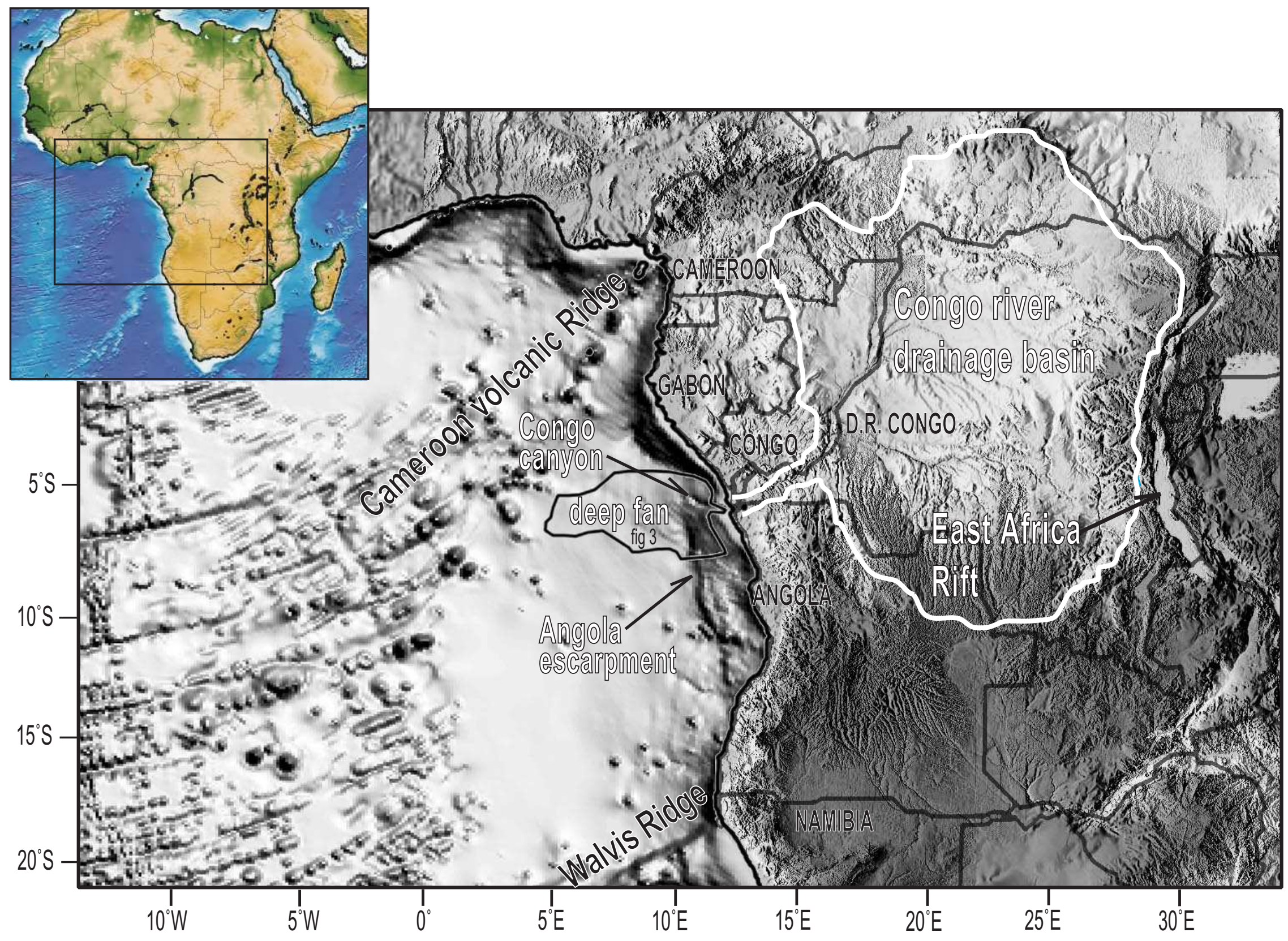

Figure 1 


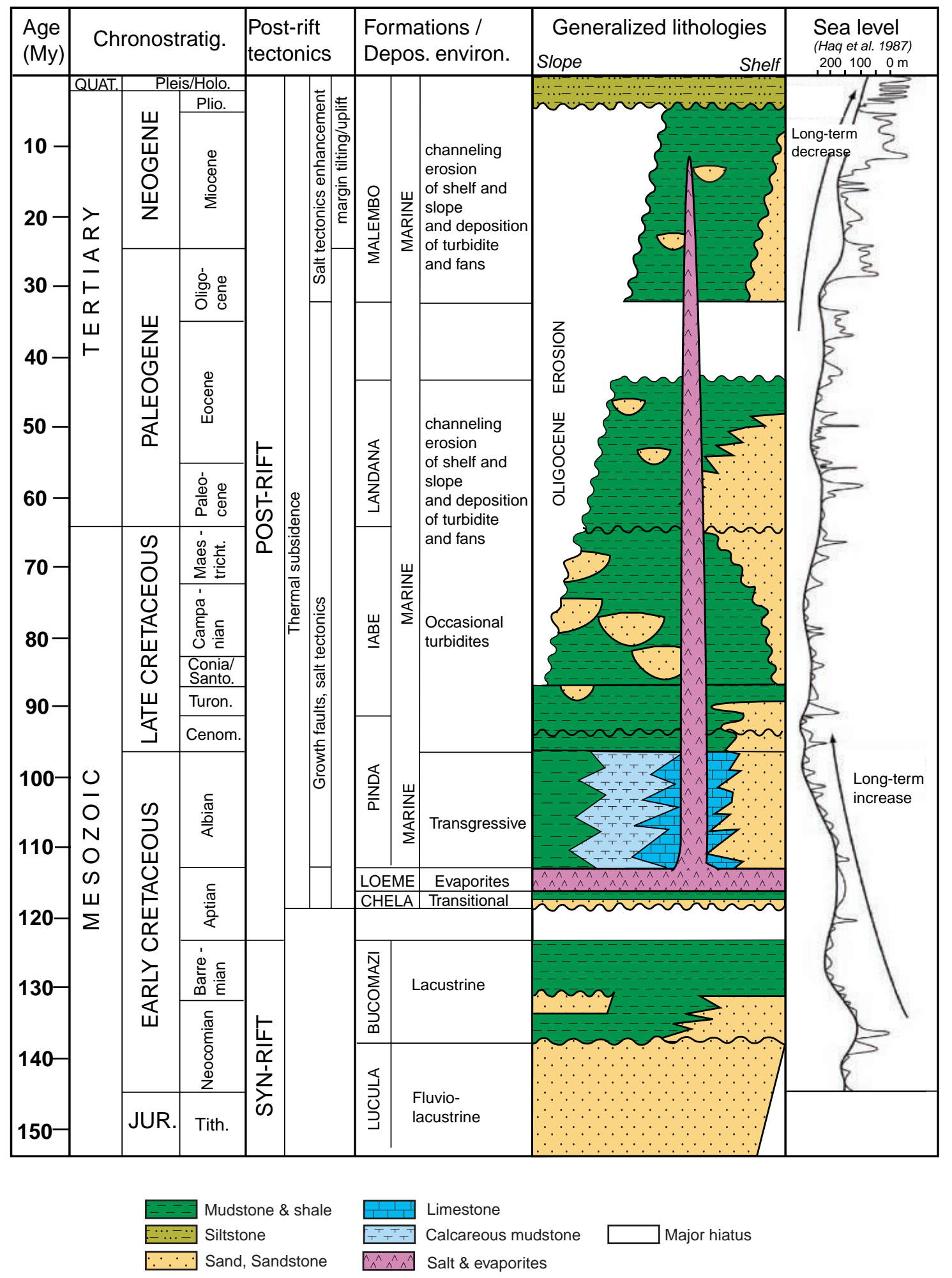

Figure 2. 


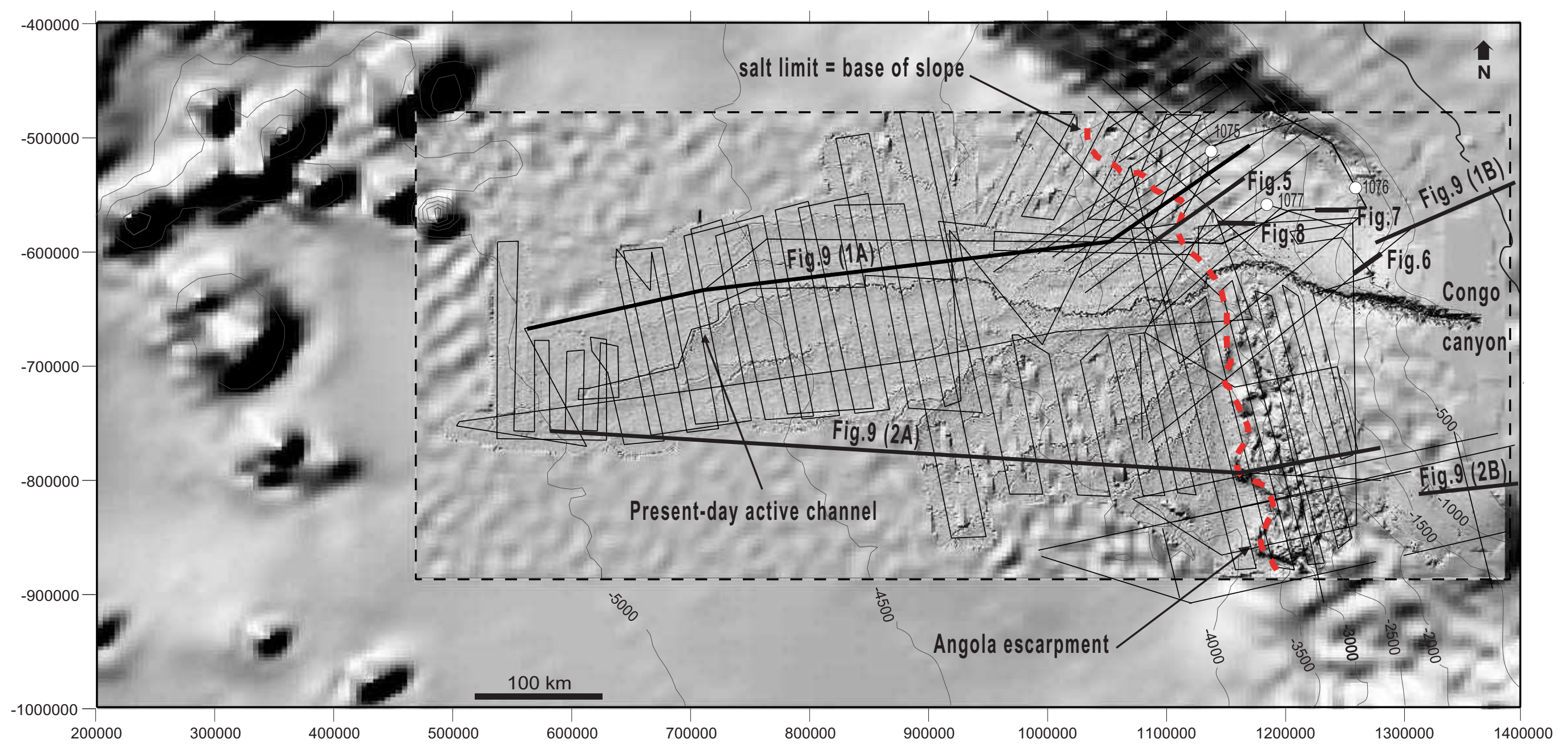

Figure 3 


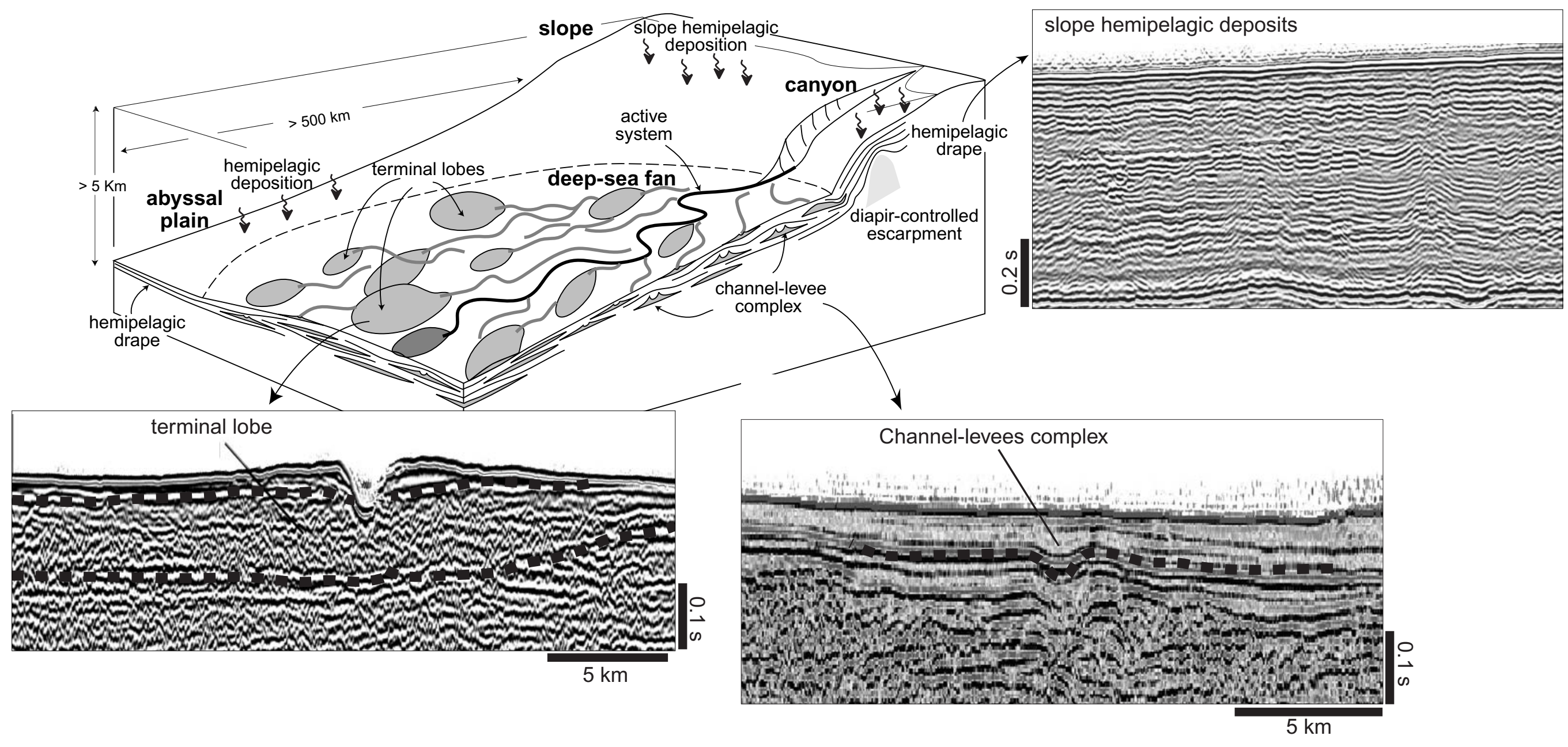

Figure 4 


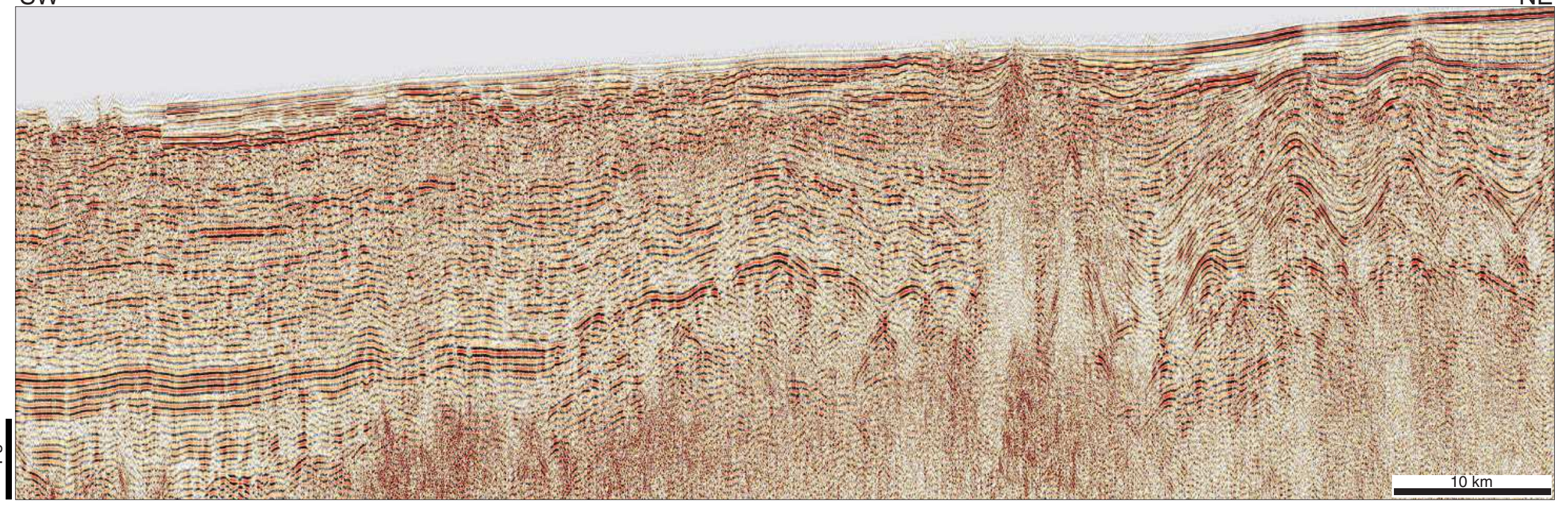

SW

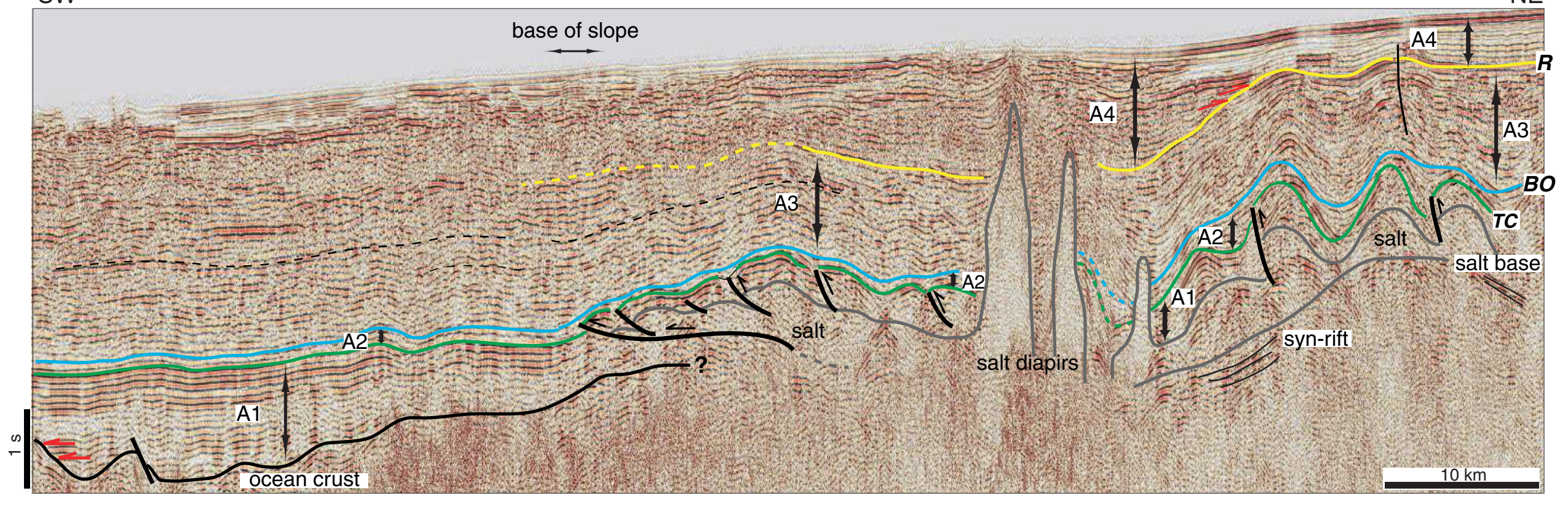

Figure 5 


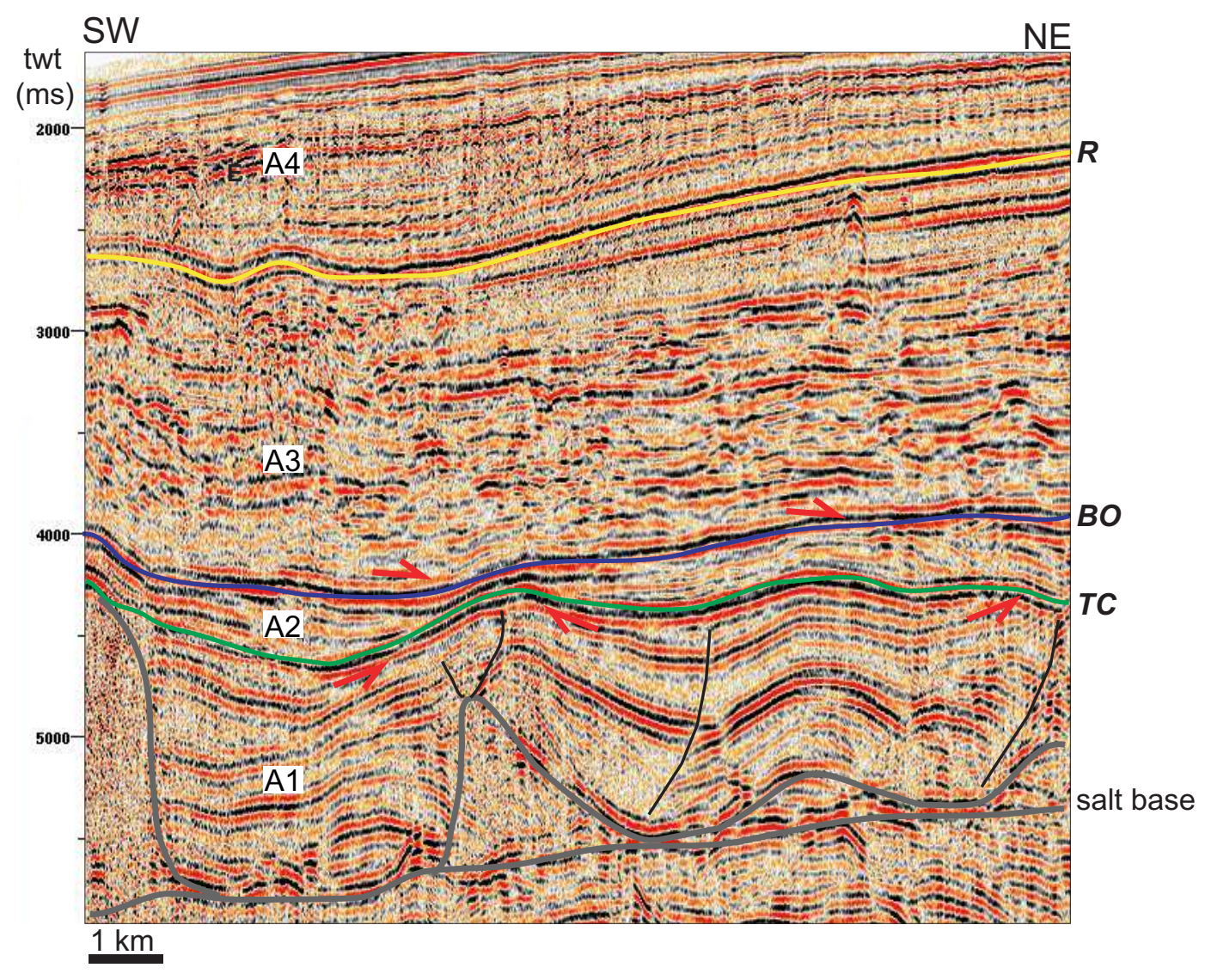

Figure 6

Figure 6 

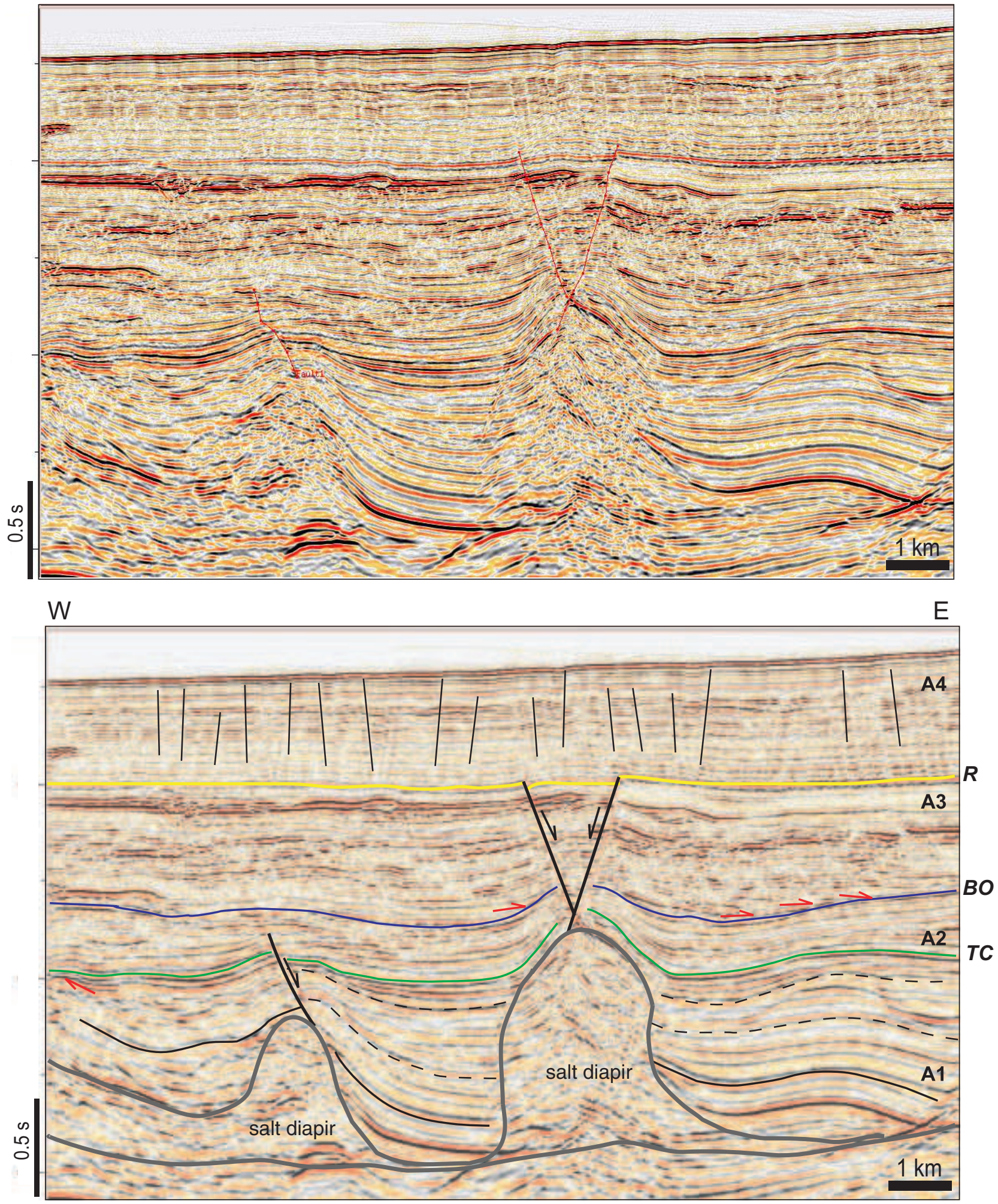

Figure 7 


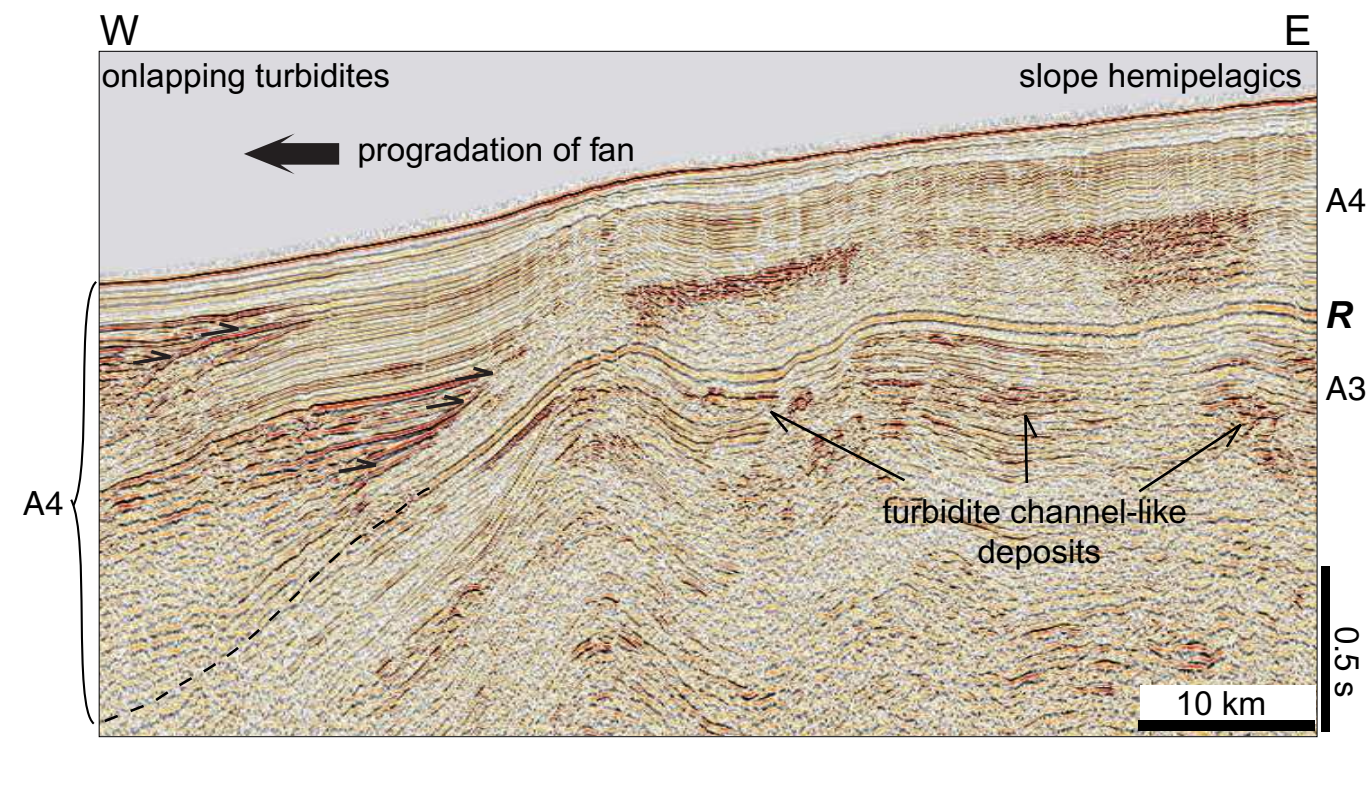

\title{
Figure 8 \\ Figure 8
}

Figure 8

onlapping turbidites

(1)

3

\author{
.
}

(

. 


$R$ : Miocene - Pliocene boundary
$\boldsymbol{B M M}$ : base mid-Miocene
$\mathbf{B O}$ : base Oligocene
$\mathrm{TC}$ : top Turonian
Aptian salt

rox. 20 km

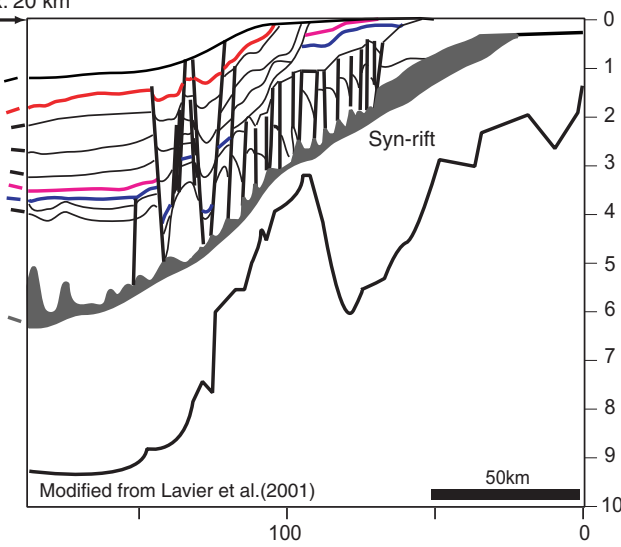

(2A)

ANGOLA

(2B)

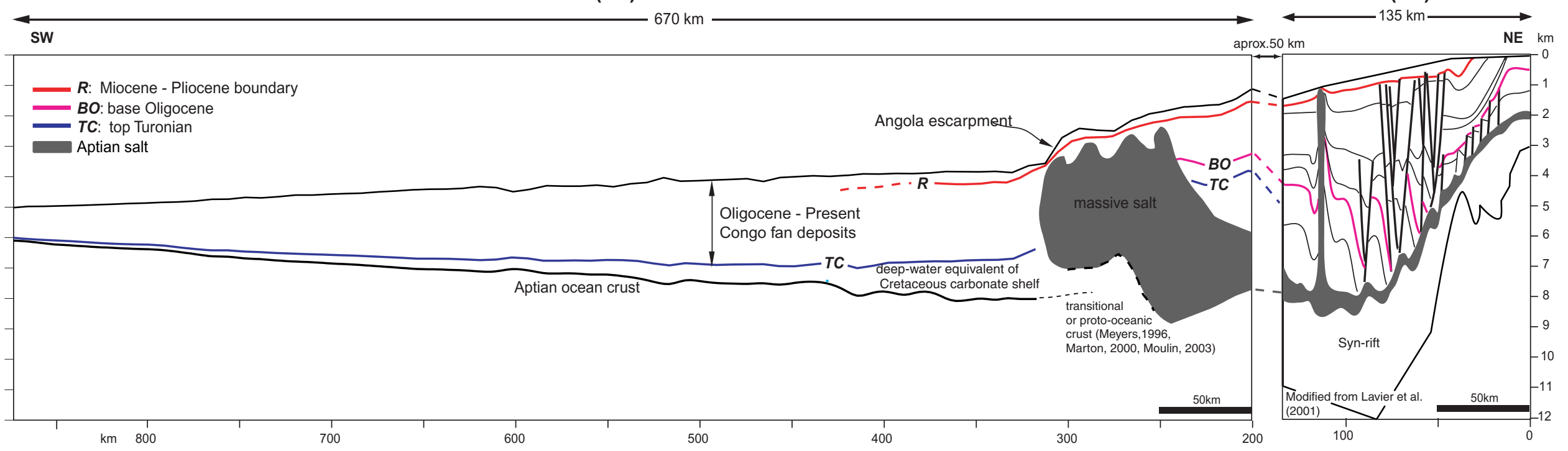

Figure 9 


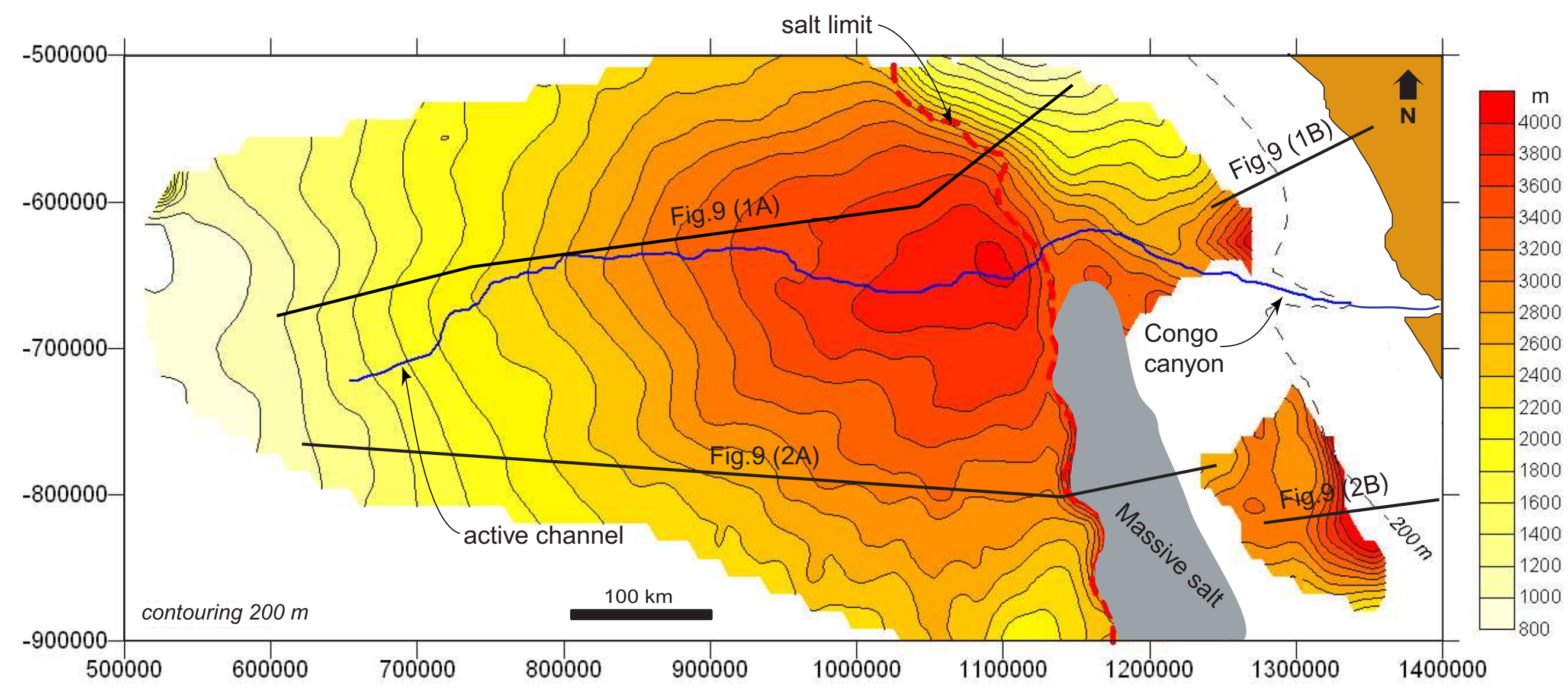

Figure 10 


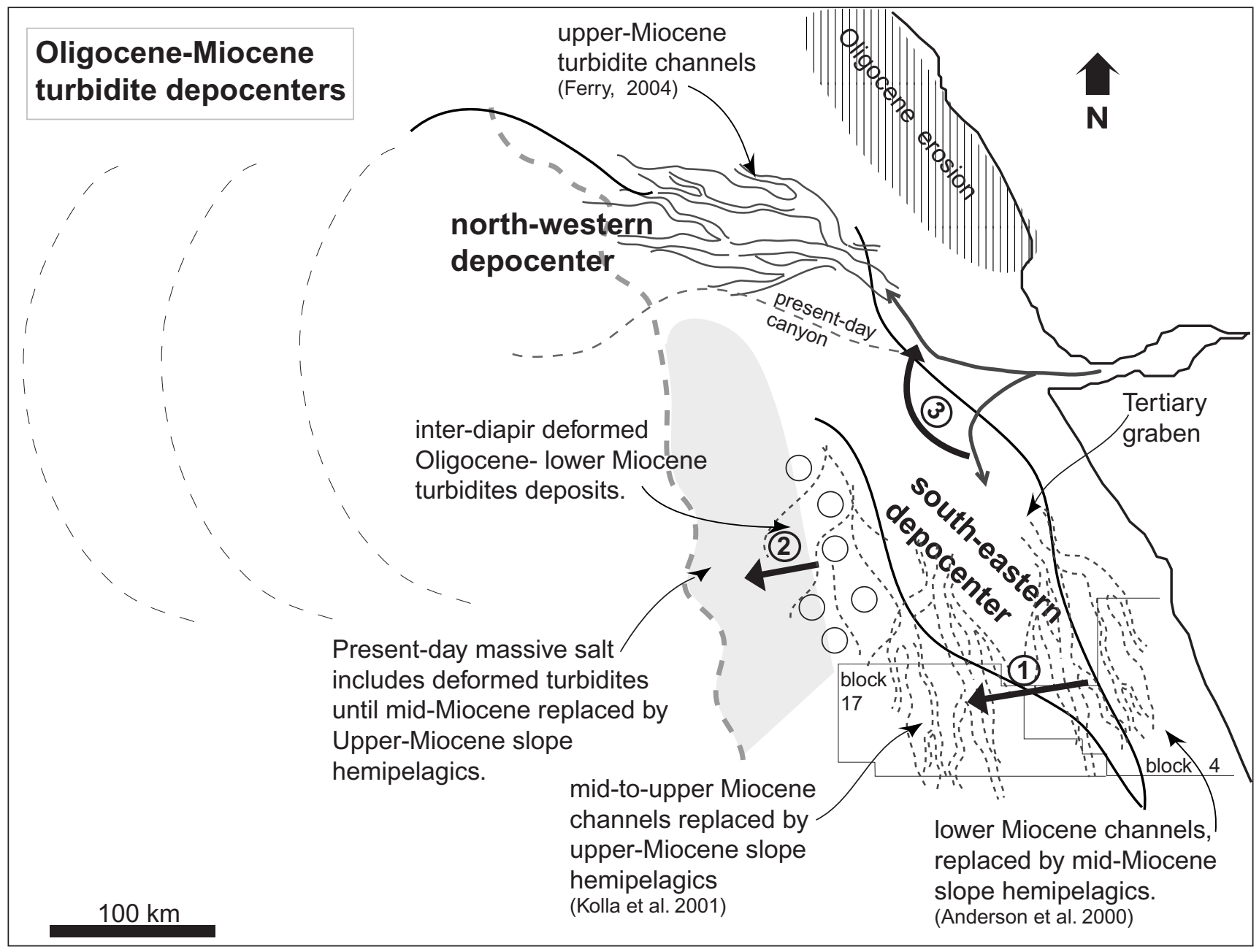

Figure 12 
a) Oligocene - early Miocene

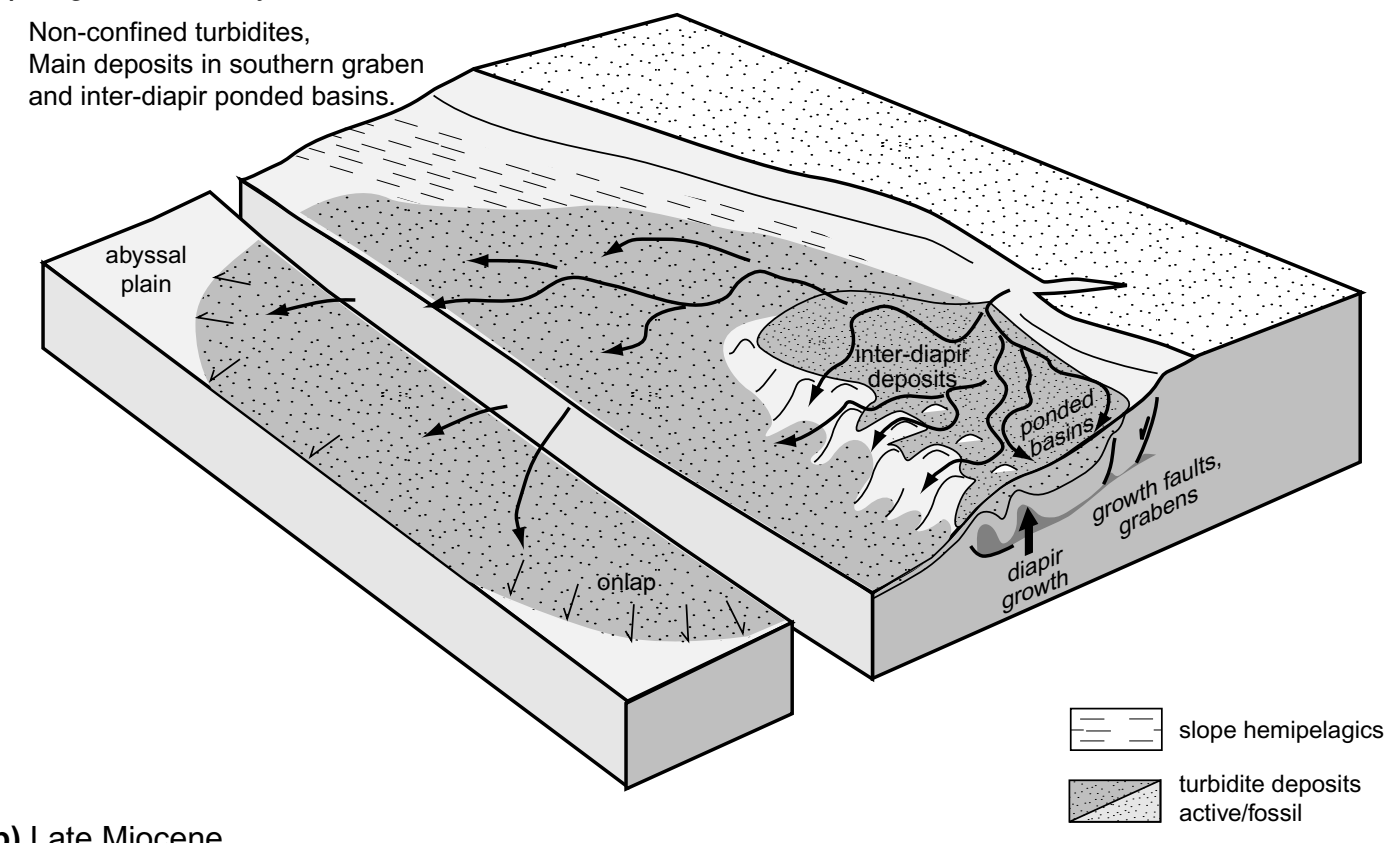

b) Late Miocene

Margin tilting \& downslope salt withdrawal.

Angola escarpment development, north-western channel migration.

c) Boundary Miocene-Pliocene

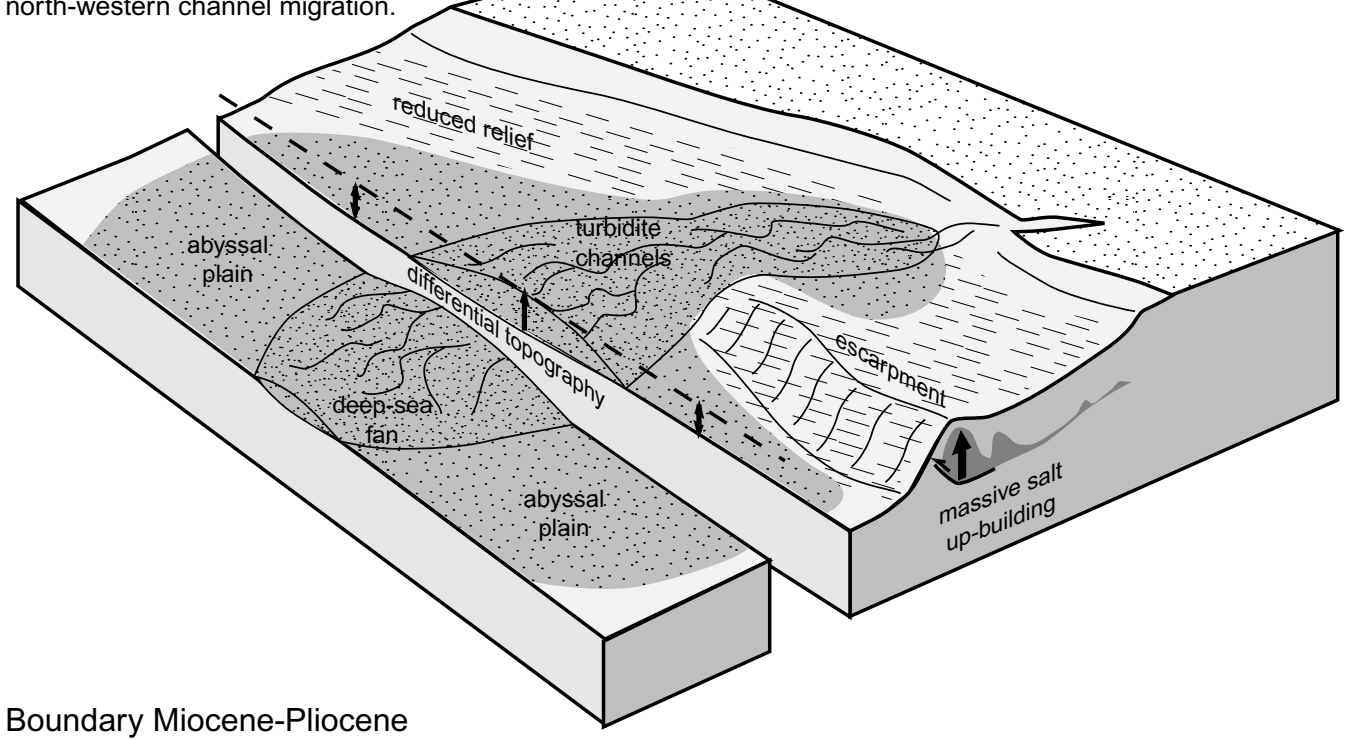

(Reflector "R" time)

Acceleration margin uplift-rate, canyon incision, confined flow, basinward progradation of deep-sea fan.

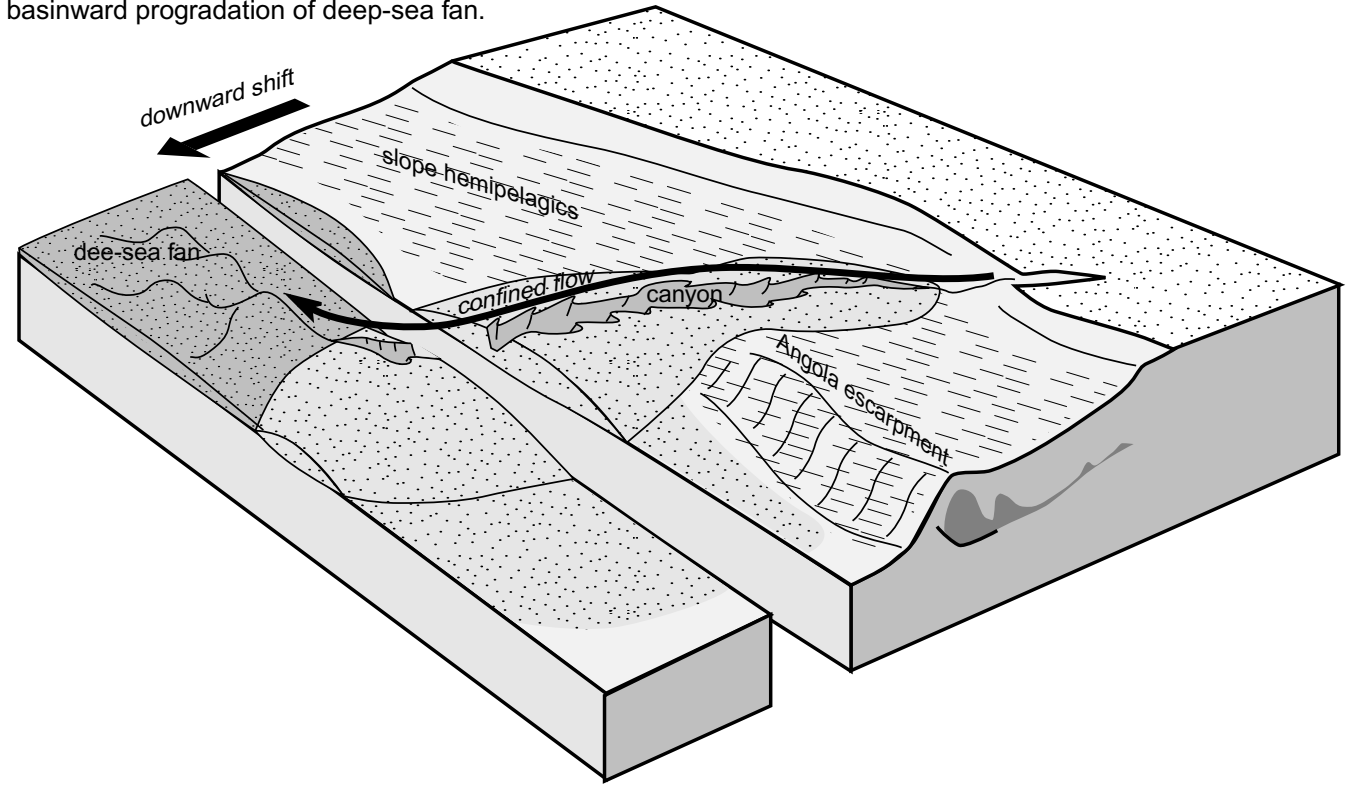

figure 13. 